\title{
Telling Tales in School: \\ Youth Culture and Conflict Narratives
}

\section{Calvin Morrill}

\section{Christine Yalda}

\author{
Madelaine Adelman \\ Michael Musheno Cindy Bejarano
}

\begin{abstract}
This study departs from mainstream criminology to approach youth conflict and violence from a youth-centered perspective drawn from cultural studies of young people and sociolegal research. To access youth orientations, we analyze experiential stories of peer conflict written by students at a multiethnic, low-income high school situated in an urban core of the western United States. We argue that youth narratives of conflict offer glimpses into how young people make sense of conflict in their everyday lives, as well as insights as to how the images and decisional bases embedded in their storytelling connect to adult-centered discourses found in popular media and formal education. Our analyses identify a range of story types ("tales"), each marked by a different narrative style, that students fashion as they write about peer conflict: "action tales," "moral tales," "expressive tales," and "rational tales." In our study, students wrote a majority of stories in the action-tale narrative style. We propose three alternative explanations for this pattern using class code, moral development, and institutional resistance perspectives. Finally, we discuss the theoretical and policy implications of our work and raise questions for future research.
\end{abstract}

or nearly three decades, stories of youth violence have claimed front-page news. ${ }^{1}$ Early accounts depicted urban youths

Portions of this article were presented at the Law \& Society Association Annual Meetings, Chicago, May 1999. Arizona State University's Multidisciplinary Initiative on Conflict and Its Management and the Center for Urban Inquiry provided funding for this project. The University of Arizona's Udall Center for Studies in Public Policy provided a Research Fellowship for Calvin Morrill during the project's fieldwork. We thank Mitch Duneier for helpful comments and Jerlyn Jones, Tawn Hauptli, Laura Ryan, William Fabricius, Mary Nell Trautner, and students, teachers, and administrators at "New West High School" for their assistance with this study. Address correspondence to Calvin Morrill at the Department of Sociology, University of Arizona, Tucson, Arizona 85721, e-mail: calvin@u.arizona.edu; or Christine Yalda, c.yalda@asu.edu; Madelaine Adelman, mad@asu.edu; Michael Musheno, musheno@asu.edu; or Cindy Bejarano, cbejaran@imap3.asu.edu, at the School of Justice Studies, Arizona State University, Tempe, Arizona 85287.

1 Indeed, the lurid details of youth violence, as reported in the mass media, both repulse and draw audiences in much the same way as adult mass murders and other forms of extreme violence. Acland (1995:10), for example, argues that "'youth' is the location of social concern and social desire, fear and pleasure" and, as such, public responses to youth violence can be read as part of a popular "spectacle." Acland further observes that “... [i]n a significant part of popular culture, murder is entertainment . . American 
of color as gangsters and violent predators, spurring school and law enforcement policies intended to curb these presumed violent tendencies among inner-city teens. Recent stories shifted attention to a string of white student shootings in suburban high schools, thus bringing an even wider range of students under public scrutiny. Taken together, these stories-about gang warfare, school-yard murders, and bullying-yield images of adolescents as either uncontrollable or unsuccessfully controlled by school, family, religious, and legal institutions.

Such stories and institutions tend to be "adult centered" in the sense that they largely are constructed, managed, and policed by adults without sustained consideration of young people's voices or concerns. Not surprisingly, adult-centered solutions to youth conflict and violence dominate contemporary public discourse about adolescents, and a wide range of political and professional interests have called for interventions to better control adolescents. Sociolegal studies of conflict and conflict management also follow an adult-centered trend. Young people, if they appear at all in sociolegal studies, enter the stage as objects to fight over (e.g., in custody cases) or as passive subjects rotating around and through adult troubles.

In sharp contrast to trends in sociolegal studies, research on young people has preoccupied criminologists at least since the 1920s, when Frederic Thrasher (1927) initiated his studies of urban American gangs. During much of the 20th century, gang studies were central to criminological inquiry about youth, and with this focus, gang researchers developed a dominant perspective about how urban youth deal with interpersonal and group trouble. This perspective emphasizes the influence of gang membership on urban youths who, for a variety of reasons, rely on violence and aggression to handle conflict. Indeed, the criminological representation of young people-particularly the literature on gangs, violence, and drugs-frames youth individually and collectively as violent and in need of discipline and punishment, which in turn informs the popular imagination (Valentine et al. 1998:10). These trends also limit systematic knowledge about how youths define and manage peer conflict. ${ }^{2}$

Our work departs from mainstream criminology to approach youth conflict from the perspectives of cultural studies of young people and the sociolegal study of conflict. We take a narrative turn by focusing on stories of interpersonal peer conflict written by students at a multiethnic high school situated in an urban

popular culture is teeming with depictions of violent acts. . . [There is a] popular fascination with the atrocious and the inventively horrible [in] ... popular culture as a whole" (1995:15).

2 So limiting and powerful are these images that, as Males (1999:29) argues, scholarly, policy, and popular "dogma" about youth reduces to a simple formula: "adolescents equal villainy." 
core of the western United States. These narratives provide preliminary evidence for understanding what we call the everyday "consciousness of conflict" among youth, which we define as the ways young people orient themselves toward, understand, and evaluate their experiences with peer conflict. ${ }^{3}$

In general, narratives enable storytellers to communicate how they make sense of lived experience (Riessman 1993). Narratives also suggest connections between daily social interaction and larger social and cultural forces that shape and are shaped by everyday experiences (Ewick \& Silbey 1995). We argue that youth narratives of conflict offer glimpses into how young people make sense of conflict in their everyday lives as well as insights into how the images and decisional bases embedded in their storytelling connect to adult-centered discourses found in popular media and formal education. Narrative analysis is particularly appropriate for exploring youth culture and conflict because writing stories enables teens to voice their own neglected perspectives on conflict and the analysis of these accounts helps us to tap into the rich, storytelling dynamics that mark youth culture (Gaines 1990; MacLeod 1987).

Popular representations of adolescents in conflict often depict them in impulsive and reactionary stereotypes. Nevertheless, we found from our analyses of youth conflict narratives that students can represent a range of reasoning processes, including rule-based and rational-choice orientations. The student authors also portrayed a gamut of conflict-handling practices they employed in which violence neither defined the context of the trouble nor dominated among their options for managing peer conflict. Our narrators realized, and told us in their own voices, how conflict constitutes and in turn is constituted by local social relations and daily routines. In contrast to sociolegal scholarship, which finds elements of legality pervasive in everyday peer conflict among adults (Ewick \& Silbey 1998), our analyses suggest that teens ground their definitions of peer conflict and their accounts of the ways they handle that conflict in extra-legal perspectives.

We begin by laying the foundations for a youth-centered approach to peer conflict vis-à-vis three theoretical traditions: criminological studies of gangs, youth cultural studies, and interpretive sociolegal research. We next describe the context in which we conducted our study, as well as our data collection and analytic procedures. In the remainder of this article, we identify and

3 As adults, we recognize that the everyday lives of young people in school settings are accessible, yet never fully knowable to outsiders, including researchers. This fact is especially true of conflict consciousness because it relates to experiences between students that largely take place without adults present. Our narrative strategy-in which we asked individual students to write a story about a recent conflict they experienced with a peer-partially overcomes these constraints by allowing youths to relate their own understandings of their experiences. 
analyze exemplars of four narrative styles (action, moral, expressive, and rational) that students used as they wrote about their experiences with peer conflict, resulting in "action tales," "moral tales," "expressive tales," and "rational tales." Finally, we offer tentative theoretical explanations for the distribution of youth conflict stories across the four narrative styles in our data set, suggest implications for sociolegal research and policy on youth conflict and culture, and raise critical questions for future research.

\section{Toward a Youth-Centered Perspective of Conflict}

Our goal in this section is to describe the conceptual foundations for constructing a youth-centered study of conflict; that is, an approach that puts youths' voices and orientations toward conflict at the center of concern. These foundations are in sharp contrast to mainstream criminological representations of youth and conflict, especially scholarship that views urban youths only through the conceptual lens of gang membership and behavior. The criminological tradition, as we will briefly review, has contributed a great deal toward understanding the causes, patterns, and control of adolescent criminality, as well as the adaptations that many youths make in urban settings. Gang and delinquency researchers, however, narrowly construct youth experience with peer conflict.

\section{Gangs, Youth Criminality, and Juvenile Justice}

Gang studies of the 1950s and the early 1960s echoed Thrasher's (1927) early work by conceptualizing urban youth gangs as dependent on violence and intimidation to maintain internal cohesion and achieve collective goals (see Cohen 1955; Miller 1958; Cloward \& Ohlin 1960; Matza \& Sykes 1961). These studies situated gangs in ongoing community life and revealed gangs as being both a disruptive and a productive influence for gang members and adults who populated the neighborhoods where gangs operated. Beginning in the late 1970s, and continuing to the present, researchers shifted their studies away from ethnic, working-class male youths to male youths of color from troubled urban cores. These studies focused on the nexus of street violence, drug trafficking, and drug use (Decker \& Van Winkle 1996). ${ }^{4}$ Popular and political accounts of the spread of violent, drug-trafficking gangs into middle-class suburbs, smaller cities and towns, and rural areas spurred the U.S. government to

4 Despite this dominant trend, a few gang researchers have attempted to counter this mainstream message by arguing for the multifunctionality and complexity of gang life (e.g., Horowitz \& Schwartz 1974; Jankowski 1991). Nonetheless, they still locate their inquiries inside, rather than outside, the gang metaphor and unintentionally reproduce the image of urban youths of color as gang members. 
create federal research funding to pursue these links (Spergel 1995). The focus on urban youth also informed public policy and resulted in the criminalization of youth behavior at ever-younger ages and an increase in the harshness with which the American juvenile justice system controls young people (Singer 1996; Feld 1999).

Facilitated in part by these trends, research on the character of juvenile criminality and its legal control has become a highly visible growth industry in criminology over the past several years, leading to the expansion of empirical work on several previously unexplored fronts. For example, a great deal has been written about the history of juvenile justice in the United States (Sutton 1988) and the gendered and racialized nature of juvenile treatment (Daly \& Maher 1998). Field studies of homeless youth (Hagan \& McCarthy 1998), incarcerated youth (Bortner \& Williams 1997), and gang members with histories of contact with the criminal justice system (Shelden et al. 1997) have also expanded the boundaries of empirical criminological research on youth. Theoretical constructs continue to grow, too, as scholars refine and extend old frameworks and call for new conceptual approaches to explain youthful criminality (Wilson \& Herrnstein 1985; Gottfredson \& Hirschi 1990; Nagin et al. 1997). ${ }^{5}$

Despite these encouraging developments, this body of work provides only a narrow window into the everyday lives of young people. Criminological research frames the most important issues relevant to youth as questions about the sources and control of criminality; in doing so, it decouples particular forms of youth behavior-especially verbal confrontations, fighting, and violations of adult authority-from the pursuit of peer grievances, conflict, and many of the issues of concern to youths themselves. Parallel to Black's (1983) arguments about the criminological study of adult conflict, criminological discourse largely defines away the importance of studying youth conflict in its own right by labeling it as "delinquency." Perhaps the closest work to a youthcentered approach to conflict comes from former and current gang members who have fashioned eye-opening solo-authored and as-told-to accounts of African-American and Latino youth lives in and out of gangs (e.g., Bing 1991; Rodriguez 1993; Cintron 1997). Whether writing about gang members or not, these authors still treat conflict and conflict management, almost by definition, through the gang lens. Missing is a systematic sense of the larger universe of peer conflict and its management among

5 It is important to emphasize that ever-changing responses to adolescent misbehavior and juvenile delinquency draw on popular understandings and social science research, both of which often rely on distorted and racialized images of "dangerous" youth. Thus, increasing academic attention (and funding) is invested into explaining interpersonal and intergroup "youth violence" both inside (Henry 2000) and outside schools (Zimring 1998), while citizens are bombarded by the media and politicians with inaccurate accounts of juvenile crime (Males 1999). 
urban young people, including the implications of the presence of adult-centered discourses and institutions (including law).

\section{Youth Cultural Studies: Contextuality, Agency, Schools, and Peer Conflict}

If criminological studies of gangs and delinquency yield a constricted view of youth conflict, studies of youth culture afford a wide-angle view. Youth cultural studies facilitate a transformation in the vocabulary of concepts; for example, from "juvenile justice," "delinquency," and "criminality" to "youth," "youth culture," and "cultural production." These changes in the research vocabulary alter one's underlying assumptions about what and who is being studied and move one closer to a youth-centered perspective on youth conflict. ${ }^{6}$

For scholars in this stream of inquiry, "youth" is a socially constructed category (Sibley 1995) located in liminal social spaces, at the blurred boundaries between "childhood" and "adulthood" (James 1986). Representations of youth are contextually bound by historical periods (Aries 1962), social and physical places (Skelton \& Valentine 1998), and discourses and practices specific to various cultures, economic regimes, laws, and mental health and scientific disciplines (Herdt \& Leavitt 1998). The contextuality of youth also extends to the construct of "youth peer cultures," which consist of "activities or routines, artifacts, values, and concerns that [youth] produce and share in interaction with peers" (Corsaro \& Eder 1990:197). Massey

6 The point of origin for this field of inquiry is arguably the Center for Contemporary Cultural Studies at the University of Birmingham in England. The "Birmingham School" initially drew on Goffman's (1963) interactionist and Becker's (1963) labeling perspectives to investigate how adult-centered legal authorities and schools label young people as deviant. Early Birmingham scholars, however, criticized the micro tendencies and explicit absence of a class basis in both Becker's and Goffman's frameworks, prompting them to embed their work in more holistic, Marxist approaches (Epstein 1998).

This shift led to the investigation of youth "subcultures," which were defined as ways of life with distinctive mores, practices, and language (Hebdige 1979; see also Schwartz 1972). Subcultures also become settings for resistance to and reproduction of dominant (middle) class (capitalist) ideology. The Birmingham group's early ethnographic and textual studies illuminated the material production of youth cultures by concentrating on the practices of adolescent boys (Cohen 1972; Willis 1977). In the late 1970s and early $1980 \mathrm{~s}$, ferninist scholars at Birmingham extended this line of inquiry to adolescent girls, especially investigating the meanings and roles of girls' leisure time (McRobbie 1980; Griffin 1985).

More recently, scholars informed by the Birmingham tradition have turned their attention to the distinctive elements of young women's subcultures by combining ethnographic and textual analyses (Valentine et al. 1998). This trend has joined ethnographic investigations of the impact of race, ethnicity, and geography on cultural signs and symbols that compose youth cultures (Gilroy 1993; Gillespie 1993; Dwyer 1998). Of course, not all works on youth culture are inspired by or resonate with the Birmingham School. Two recent popular books illustrate treatments of youth culture from very different premises. Hersch (1999) presents contemporary American youth as an exotic "tribe apart," abandoned by a generation of self-involved parents. Harris (1998) draws from developmental psychology to argue that it is peers (hence, youth culture) rather than parents who decisively socialize children. 
(1998:124) sharpens the linkages between local youth peer cultures and wider social domains by arguing that we think in terms of multiple youth cultures that arise from "particular articulation [s] of contacts and influences drawn from a variety of places scattered, according to power relations, fashions, habit, across many different parts of the globe." Conceptually, then, youth culture becomes an amalgam of symbolic, material, and normative elements that are produced via local interaction but that are tied into regional, national, and even global sociocultural and economic forces. ${ }^{7}$

To understand a "particular articulation" of youth culture means coming face-to-face with young people at the sites where they make and have their lives made (by adults) on a daily basis. Recent critical ethnographies of schooling offer such entrée and provide another strand of research that informs our work. These studies examine how schools culturally produce "educated persons" and create the institutional terrain on which students develop their social and personal "selves," bodies, aspirations, and political outlooks (Levinson \& Holland 1996). Among the key topics considered in this research is the moral authority of curricula, teachers, and administrators, as well as student resistance to such authority. Ethnographies covering these and similar themes are available concerning middle-school adolescents (Thorne 1994; Eder 1995), students in inner-city public high schools (Fine 1991; Devine 1996), and "preppies" in elite, private, single-sex high schools for girls (Proweller 1998). ${ }^{8}$ In their explorations of school life, school ethnographers also provide clues about the meaning, management, and consequences of peer conflict among young people. Indeed, some researchers argue that peer conflict is a central theme in the lives of youths as it constructs

7 To this conceptual mix, Henry Giroux (1998) adds an explicitly political dimension by focusing on "streets" and schools as "sites" of youth resistance to dominant adult cultures (see also Levinson 1998, on the uses and consequences of moral discourse in political resistance in a Mexican secondary school). Giroux (1998:48) deconstructs popular representations of youth to demonstrate how "youth becomes an empty category inhibited by the desires, fantasies and interests of the adult world." Once understood in this light, Giroux believes that material signs and routine practices of youth subcultures can subvert and transgress hegemonic adult culture. The mechanism for such a transformation, Giroux (1998) argues, is a "progressive cultural politics" facilitated by a critical pedagogy that affords young people "the opportunity to narrate themselves, to speak from the actual places where their experiences are shaped and mediated. ... [This] means providing the conditions-institutional, economic, spiritual, and cultural-that allow them to conceptualize themselves as citizens and develop a sense of what it means to fight for important social and political issues that affect their lives, bodies, and society." Giroux's call for a critical pedagogy that seeks to understand and transform relations of power and knowledge remains a critical theme in his work (Giroux 1996), as well as implicitly in our own work.

8 Recent research also examines how these themes play out among working young people who are just beyond secondary school (Fine \& Weis 1998), while comparative historical research addresses the historical and cross-cultural implications of schooling processes and practices, including their relation to law (e.g., Bourdieu \& Passeron 1977). 
and reconstructs local contexts, including peer social ties and hierarchies (Corsaro \& Eder 1990:214; Adler \& Adler 1998).

We take away several insights from work on youth culture that we build into our approach. First, our methods resonate with the idea of treating young people's experiences and pronouncements contextually, which means moving beyond stereotypical images of youth "gangsters" to explore the diversity of youth experiences. Second, we begin with the interpretive assumption that youths actively construct meaningful cultural representations, rather than passively absorbing both consumer culture and school curricula. Third, we believe in adopting methodological orientations that facilitate self-representation by youth and are capable of directly accessing youth voices and concerns. Fourth, youth cultural scholars remind us that schools are strategic sites where youths struggle to make sense of the worlds they create and re-create with peers and adults. As touched upon by school ethnographers, peer conflict is presumed to be central to sense-making among youths. Despite this important insight, these researchers provide little sustained attention to peer conflict per se in adolescent contexts. ${ }^{9}$ As a result, we turn to sociolegal perspectives to focus our analytic lens on conflict.

\section{Sociolegal Perspectives: From Disputing to Narrative Analysis}

As we noted at the outset of this article, sociolegal scholarship does not seek youth perspectives directly. Like law itself, sociolegal scholarship generally treats young people as passive subjects and objects of adult action. When youths occupy centerstage in legal and sociolegal research, scholars typically focus on minors' place, well-being, and safety from the perspective of adult legality. One line of research, for example, examines how judges and other officials establish and maintain "best-interestsof-the-child" standards in child custody cases (Fineman 1991). Other scholars investigate connections between violence, family law, and minors, including the ways abusive partners use their children as leverage in family law proceedings to harm or maintain control over their partners (Dobash \& Dobash 1979; Adelman 1997). Still other scholars write about young people in relation to legal adoption (Ynvesson 1997). These works offer valuable insights about how the interests and perspectives of children are established via legal and other forms of adult decisionmaking. However, they give little direct attention to young people's experiences, concerns, or voices in these processes. ${ }^{10}$ More

9 Conflict research among younger children is much more developed. See, e.g., Corsaro \& Rizzo (1990) on peer conflict among nursery school children, and Maynard (1985) on the processes by which peer conflict builds social structure among young children.

10 An exception to this trend is Wright (in press), who focuses on children's experiences in famiiies headed by gay and lesbian parents. 
importantly for our purposes, they do not address young peoples' consciousness of peer conflict in everyday contexts. Despite the lack of youth-centered inquiry, we draw on three strands of sociolegal scholarship that can offer useful points of departure for studying youth conflict: the "disputing" paradigm, the interpretivist shift to studying "legal consciousness" in everyday life, and a spin-off from that approach, narrative analysis.

Early researchers in the disputing paradigm hoped to reveal the rules and mechanisms that enable societies to hold together as functional wholes (Roberts 1979). ${ }^{11}$ During the 1970s, anthropologists criticized this line of inquiry as ethnocentric because it largely denied the plurality of law and diverse normative orderings across and within societies (Moore 1973). This critique facilitated the development of nonfunctionalist frameworks for analyzing the processes by which disputes are structured and transformed within and without legal contexts. Rather than focusing on the contribution of dispute processing to social order, scholars concentrated on generating the contextual factors that influenced the emergence, processing, and outcomes of disputes, including: the roles, relationships, and social power of the parties; cultural differences between the parties; the availability and actions of third parties and disputing forums, including supporters, audiences, judges, mediators, and lawyers; and the substance of the dispute (Black 1976; Nader \& Todd 1978).

As sociolegal scholars turned their attention to the cultural side of disputing in the 1980 s, the disputing paradigm took an interpretive turn with conceptual frameworks that articulated the developmental stages of disputes and the transformations of meaning at each stage (Felstiner et al. 1980-81). Interpretivists shifted the focus of research from disputes to processes by which people make sense of law, legal institutions, and legal processes in their everyday lives (Merry 1990; Sarat 1990). With this shift, "legal consciousness" (the emergent frames and orientations that people interactively develop about law) and "legality" (law and law-like principles that people use in decisionmaking) shared top billing and, among many sociolegal scholars, replaced "disputing" as a master concept. No longer could conflict be regarded as violations of a singular normative order. Contested interpretations of trouble and the multiple meanings of conflict became grist for the sociolegal mill. ${ }^{12}$

11 The early line of inquiry in the disputing paradigm arose from the functionalist assumption that all societies "need" dispute resolution institutions to maintain order (Roberts 1979). Llewellyn and Hobel (1941:21) helped to consolidate this tradition with their "trouble case method" that searched for instances of "hitch, dispute, grievance, trouble ... and what was done about it." Scholars using this method often assumed conflict began with grievances that stemmed from violations of a singular normative order associated with a particular society.

12 This movement also facilitated the expansion of sociolegal inquiry to understand settings and issues previously unstudied or understudied by sociolegal scholars, including 
More recently, interpretivist sociolegal scholars have generated narrative data to tap into the consciousness of legality and conflict. Narrative analysis specifically plays off how people commonly constitute memory through their stories about lived experience during particular events and longer stretches of time (Ewick \& Silbey 1995; see also Schank 1990). ${ }^{13}$ Narratives therefore act as "frames" (Goffman 1974) that people generate interactively to make sense of and organize phenomena (including conflict). Among youths as among adults, people also embed different reasoning strategies and modes of self-representation in narratives of conflict and moral decisionmaking (Gilligan 1982; 1988). ${ }^{14}$

Sociolegal scholars have put these general ideas to use in a variety of ways. Conley and O'Barr (1990), for instance, argue that whether lower-court disputants tell stories via "rule-oriented" discourse (in which problems are framed in legal categories and rights) or "relationally-oriented" discourse (in which problems are framed around relational ties and contexts) colors how aggrieved parties define themselves in relation to their adversaries, their grievances, what is at stake, the desirability of various resolutions, and ultimately success or failure at attaining their desired ends in front of a judge. In addition to providing access into individual lived experiences, stories reveal how dominant social and cultural forces enable and constrain local experiences, as well as how people speak back to such orderings, including law (Ewick \& Silbey 1995). Because storytelling also is about the projection

ethnic communities and marginalized peoples, corporate and transnational elites, the significance of identity and place, and resistance to and through law (e.g., Cooney 1998; Nader 1990; Morrill 1995; Dezalay \& Garth 1996; Espeland 1998; Hirsch 1998; Tucker 1999).

13 Narrative analysis also links with several old and new developments in sociolegal theory, and the social sciences, more generally. It is reminiscent-albeit with different ontological assumptions-of classical work in the anthropology of law on "extended cases" recovered from informants' memories (Van Velsen 1967). The use of stories is part of the historical legacy of Chicago School sociologists, as well, who used them to study the concerns and aspirations of urban immigrants and other city dwellers (Abbot 1992). Storytelling also intertwines with long-standing sociolinguistic and interactionist perspectives on language-in-use, especially the vocabularies of motive people use to make sense of their actions (Mills 1940) and to account for their troubles (Scott \& Lyman 1968). Feminist epistemology provides a more recent theoretical impetus for narrative analysis by recognizing the experiential grounding of knowledge and how dominant social representations of reality mask the experiences of women and other minority stake holders (Dobash \& Dobash 1979).

14 We should note the minimal elements that a communication must exhibit to be considered a narrative: "selection," "emplotment," and "interpretation" (Riessman 1993). Selection refers to the sorting of past, future, or imagined experiences into a limited number of events that compose the scenes of a narrative. Emplotment involves the linking together of events and people into causal, associational, or sequential patterns. Interpretation requires inferences (either implicit or explicit) about what the plot and events mean to both the narrativist and audience. That spoken or written communication carries these elements does not imply how detailed a narrative is, its length, or content. Narratives can be quite intricate, as in a novel, or truncated, as in a quick story told to account for why one uds late to work. 
of one's self, narrative data enable insights into how narrators define, negotiate, and perform roles and identities in a given context (Oberweis \& Musheno 1999). Some sociolegal scholarship adds an even longer-term historical dimension to narrative analysis by taking a life-history approach. Engel and Munger (1996), for example, use biographical stories to trace whether and how legality emerges in the lives of citizens from childhood to adulthood. Miller (1990) delves even deeper into the depths of history by analyzing 13th century Icelandic "sagas" to recover the sociocultural foundations of legal consciousness, social control and governance in stateless societies.

In combination, sociolegal narrative analysis and youth cultural studies suggest a number of exploratory research questions that guide our study: (1) How do youths represent everyday conflict in their stories? (2) What decision-making and reasoning processes do youths produce in their stories about conflict? (3) How do young people represent various means for handling peer conflict? (4) How is violence portrayed in their narratives? (5) How are adults situated in youth conflict narratives? In the next section, we briefly describe the context of the study and then turn to the methods we used to investigate these questions.

\section{Study Context: New West High School}

Founded in 1908, "New West High School" (a pseudonym) is located in an urban area in a large metropolitan region that has grown precipitously during the last two decades. It enrolls approximately 1,300 students, and according to official school data, its students are: 45\% "white," 31\% "Hispanic," 16\% "black," 5\% "Asian," 2\% "Native American," and 1\% "other." The majority of the students $(65 \%)$ come from households earning between $\$ 30,000$ and $\$ 39,000$ per year. Nearly $20 \%$ of the students live in households whose incomes fall below the poverty line, and only $3 \%$ come from families earning more than $\$ 40,000$ per year. ${ }^{15}$

Over the past several years, New West High's students have collectively scored lowest in standardized examinations given in the "Crossroads District" (a pseudonym). At the same time, its students scored considerably higher than those who attend the urban high schools of the larger school district that abuts New West's. Unlike some of the other schools in its district, New West has a reputation for relatively little campus gang activity. New West also enjoys a stable faculty that is considered innovative by district officials and teachers at other schools in its district.

15 Income information is missing for the remaining $12 \%$ of households. 


\section{Collecting and Analyzing Youth Narratives}

To address our research questions, we conducted a "narrative survey" of students at New West High in December 1997, as part of a larger field study of youth conflict. ${ }^{16}$ Modified versions of this approach have been used effectively to collect narratives on legality and legal consciousness (Ewick \& Silbey 1998), decisionmaking processes among street-level bureaucrats (MaynardMoody \& Musheno 2000), and conceptions of violence among urban youths (Ward 1988). In one of their regular classes, each participant in the study was asked to write a story about an interpersonal peer conflict he or she had experienced.

\section{Participants}

Our participants $(N=358)$ consisted of all ninth graders enrolled during the 1997-1998 academic year at New West High. Of the students we surveyed, $53 \%$ are male, $47 \%$ are female. The ethnic makeup of the sample is similar to the overall student population at New West, with $47 \%$ white, $23 \%$ Hispanic, $14 \%$ black, $4 \%$ Asian, and $1 \%$ Native American. We surveyed ninth graders for several reasons. First, we have an ongoing partnership with New West's Department of English to assist its faculty in developing instructional materials for ninth grade English classes that engage students in a variety of nonviolent methods of conflict management. The materials encourage faculty to include youth voices in the ninth grade curriculum by drawing on youths' everyday knowledge of conflict in focus groups and youth narratives about conflict. ${ }^{17}$ Second, because we collected all of our narratives simultaneously in English classes, we avoided the risk of contamination across subgroups of students. Third, ninth grade is an important transition period for students at New West because they are newly arrived from middle school. More generally, the literature on adolescent development (Gilligan 1988) suggests that in early adolescence (i.e., students aged 12-15 who

16 The larger field study, from which the present data is drawn, consisted of a twoyear team ethnography of youth conflict and culture, supplemented with (1) youth-generated photographic and mapping data on the sociophysical aspects of New West, (2) biographical and focus-group interviews with samples of students, teachers, administrators, and security personnel, and (3) institutional data drawn from official sources at New West, Crossroads School District, and its surrounding community.

17 Instructional materials have taken the form of a curricular workbook that uses exercises, student narratives (drawn from the present study), and American literature to encourage students to explore their own understandings and experiences with conflict. The Conflict Resolution Workbook: Developing Positive Methods to Handle Conflict Through Language Arts Instructions (compiled by Tawn Hauptli \& Laura Ryan, teachers at New West) also asks teachers to engage in a paradigm shift away from teacher-centered pedagogy to a student-centered approach that encourages teacher-facilitated, student discovery of knowledge. The underlying theme of the Workbook thus embraces a "critical pedagogy" in which the everyday lives of students are authenticated in the classroom (see Aronowitz \& Giroux 1993). 
are entering high school and/or in the highest grades of middle school), youths are quite sensitive to and interested in the boundaries of appropriate behavior, their new places in high school, and their experiences during middle school. We also believed these factors would motivate our participants to share their experiences through storytelling. Our expectations proved accurate, as we found students quite willing to respond to the survey: Eighty-eight percent $(N=316)$ of the students completed the exercise.

\section{Procedures}

We fielded our instrument to every New West ninth grade English class. This context proved to be conducive for the survey because the "narrative exercise," as we introduced it to students, was a natural extension to students' routine assignments, with two important exceptions: First, students could opt out of the exercise by leaving the page available for writing their story blank or by writing on that page that they declined to write a narrative. ${ }^{18}$ Second, unlike a class assignment, we explicitly protected student identities by using unique ID numbers to identify narratives. At the beginning of the exercise, we explained the nature of the exercise and that students would have as much time as they needed to complete it. Students were also instructed to complete the exercise "on their own" without discussion among their peers. On the page provided for the narrative, the following prompt appeared:

Think of a time you experienced a conflict with another student. Did you know the student? Where were you? How did the conflict begin? What happened? Was anyone else involved? Express what was going on in your mind before, during, and after the conflict. Was it resolved? How?

The prompt directed students to write about interpersonal conflict with another student, rather than intergroup conflict. It also facilitated students putting their thoughts in a narrative format, focused students on their own senses of conflict, and left open the meanings of "conflict" and "resolve." A section at the end of the survey asked for demographic information on ethnicity, sex, and age. Of the 313 narratives produced by students, we excluded 46 for three reasons: (1) they are unintelligible; (2) they primarily involve intergroup rather than interpersonal conflict; (3) they involve events from elementary school, which we deemed too remote from our concerns with early adolescence. Thus, the data in this analysis consisted of 267 narratives.

18 We were sensitive to the implicit pressure on students to complete the exercise and provided alternative means for students to "opt into" (Alderson 1995) our research in settings outside of the classroom (as participants in our larger ethnographic project at the school or in focus-group settings apart from the narrative survey). 


\section{Analysis}

We first transcribed the narratives from their original handwritten forms into a typed data set, being careful to preserve spelling, grammar, and narrative structure in their original form. During our initial readings of the narratives, it became clear to us that each conflict narrative, like any story, comprises different modes of representing reality (White 1981). When we read the narratives as stories, rather than as constellations of discrete content elements, we saw that our student narrators, like novelists and ethnographic writers, have different authorial "voices" and fashion different styles of storytelling through the use of plot structures, dramatic tensions, and dramatic resolutions (Van Maanen 1988). But their stories are not merely compilations of naturalistic literary devices either. As Thompson (1990:284) reminds us, "[S]ymbolic forms are contextualized products . . . [that] claim to say something about something." That "something" is a student's consciousness of conflict and sense of self as manifested in discursive practices (Conley \& O'Barr 1990) and reasoning processes (Gilligan 1988). Our analysis therefore turned to identifying the types of authorial voice in the narratives; that is, how each author marked his or her style of storytelling, thus signaling his or her understanding of self in relation to peer conflict, conflict management, and decisionmaking. ${ }^{19}$

Based on our readings, we identified four types of stories: action tales, in which the author represents him- or herself and others as acting within the parameters of taken-for-granted assumptions about what is expected for particular roles among peers; expressive tales, in which the author focuses on strong, negative emotional responses to someone who has wronged him or her; moral tales, in which the author recounts explicit norms that shaped his or her behavior in the story and influenced the behavior of others; and rational tales, in which the author represents him- or herself as a rational decisionmaker navigating through the events of the story. ${ }^{20}$

19 To some readers, using so lofty a term as authorial voice in the context of an analysis of students in their early teens may seem pretentious. Devine (1996:166-71), for example, criticizes privileging of student voices by calling it the "student-as-oracle" approach. We do not pretend that students have "all the answers," but we do believe that not treating students as authors in the context of this study, with distinctive voices and styles, falls prey to the same kinds of criticism we earlier leveled at adult-centered perspectives and images of youth.

20 Our action, moral, and rational categories resonate with modes of decisionmaking generally found in legal contexts (see Suchman 1997). We also elaborated the story categories along four dimensions to better identify each one: (1) plot structure (how the story is structured; for example, whether the story unfolds "linearly," largely moving sequentially from scene to scene, or "nonlinearly," with rich allusions to other phenomena, including reflections on reasoning strategies); (2) dramatic tension (how the central opposition in the story is represented); (3) dramatic resolution (how the dramatic tension in the story is solved); and (4) predominant outcomes (how the story ends; e.g., "deterrence," "reputational maintenance," "normative maintenance," "relational (re)construction"). 
Our coding strategy specifically consisted of categorizing each story into one of the four story types, recognizing that an author could produce a "blended" story in which more than one style was equally featured. We identified thirteen of these stories, but we do not analyze them here because of space limitations. The number of stories used to calculate all percentages in the following sections therefore is 254 .

Finally, to assess the interpretive consistency of our coding, we conducted an internal audit (Lincoln \& Guba 1985) by revisiting, through group discussion among the first two authors, the conventions that mark each story style. During the audit, a formal reliability analysis yielded a Cohen's Kappa of 0.82 between the primary coders (the first two authors). Our audit also sharpened the story categories. ${ }^{21}$

\section{Narrating Youth Conflict}

To move from one narrative style to another is to move across different ways of making sense of peer conflict. Even so, three general patterns cut across nearly all of the narratives. First, all of

Standard literary usage informs the first three of these categories: plot, dramatic tension, and dramatic resolution (Beckson \& Ganz 1999).

21 Despite the strengths of our methodological strategy, we recognize its limitations. First, we realize the context in which we elicited the narratives could influence what the students produced. Our storytellers wrote these narratives as part of a class exercise, rather than producing them in the schoolyard or on the street. Given the expectations and norms associated with "classrooms" and with the exercise being part of a "university study," our survey ran the risk of either collecting sanitized stories (in which students tried not to reveal too much) or embellished stories to "shock" the researchers. Undoubtedly, writers sanitized, embellished, and, in some cases, completely fictionalized their stories. At the same time, we believe that the context in which the exercise occurred (English classes) and the confidentiality of the students' writings created an environment of relative safety in which students believed they could straightforwardly express themselves, which is consistent with other accounts-based sociolegal research using students of various ages (e.g., Katz 1988:52-79; Henry \& Eaton 1999). Our informal discussions with students in the ethnographic component of the larger study of which this analysis is a part also confirm the seriousness with which students approached the study and similarities between what students wrote about and their behaviors on and around campus. Indeed, there is a kind of "linguistic realism" attached by the students to their narratives in which they believe, to borrow from Cintron $(2000: 50)$, that they "have the ability to say what they mean, and . . . what they say is true." Moreover, we take seriously the theoretical argument that narratives do not only "reflect" experience, but in part constitute it (Ewick \& Silbey 1995). What this means is that the stories we collected in part define the realities of conflict as students themselves see them.

A more troubling limitation for our analysis may be constraints on our sample in terms of age, experience with New West High (most participants had been at the school for approximately six months), and writing skills. In terms of age, it is true that a 17-yearold (or an adult) can see the world quite differently than a 14-year-old. One should remember, however, that age itself is not a prerequisite for insight into the world or the ability to express one's self, as our narrators amply demonstrate. Finally, writing skills certainly constrained our abilities to discern meaning in the stories. We cannot know whether the perspectives of those students whose narratives we excluded because they were unintelligible were different from the narratives we coded. The narratives in the data set exhibit a range of prose skills, from rather inarticulate writers to writers with considerable abilities. Therefore, we believe we have a reasonably wide range of writing abilities within the coded data set. 
the authors, save for five, write about trouble flowing from someone or something else that is then resolved by the author. The author typically describes his or her contribution to the scene as a respondent rather than a provocateur. Thus, most authors explicitly or implicitly absolve themselves of primary responsibility for causing whatever trouble they face. Second, students rarely write about adult intervention into their conflicts. When adults do intervene, it is typically after much of the conflict has played itself out among peers. Finally, one senses a powerful resilience in most narrators that cuts across all of the tales. Even if dramatic tensions are left unresolved in a story or lingering doubts remain in the narrator's mind about how he or she handled a situation, most authors give the impression of moving on in their lives to face the next scene or set of issues. In the next subsections, we organize our discussion around story types in descending order of their prevalence in the data set. We concentrate our attention on several exemplars selected to highlight particular aspects of each type.

\section{Action Tales}

The most common narrative in our data set is the action tale $(57 \% ; N=144)$. Action tales unfold in matter-of-fact tones kindled by dramatic tensions that begin with a disruption of the quotidian order of everyday routines. A shove, a bump, a look, a rumor sometimes "out of the blue," triggers a response that reinscribes taken-for-granted assumptions about the nature of personal ties, the performance of particular roles, the upholding of identity, and the relational competence youth feel they possess among their peers. Indeed, authors of action tales often state that there was "no reason" for how the events of a conflict unfolded, except that it "had to go that way"-a kind of interpersonal path dependency rooted in unstated expectations. Authors of action tales typically organize their plots as linear streams of events as they move briskly through the story's scenes. The male author of Story 1 focuses on an incident in the school lunch line:

Story 1

Yes I knew the student. I was at lunch standing in line and he came up to my face and started saying stuff and then he pushed me. He was saying that I wasn't to fight him. I said I didn't say that plus I'm cool with you, I'm your friend and then he push me again and calling me names. I told him to stop pushing me and then he push me hard and said something about my mom. And then he hit me, and I hit him back. After he fell I started kicking him. $[049]^{22}$

22 The number in brackets at the end of each narrative exemplar refers to the narrative identification number in the data set. 
The first sentence of this story responds directly to a portion of the prompt in the narrative exercise ("Did you know the student?"). After this opening, the author immediately presents the dramatic tension of the story, which consists of the antagonist "saying stuff" (delivering personal affronts), physically pushing the author, and implying that the author would not fight him (i.e., an affront to the author's reputation). The first attempted resolution to this tension occurs when the author alludes to an unstated expectation that "friends" are "cool" with each other; that is, they do not fight each other. The situation intensifies as the author tries to stop the action by telling his antagonist "to stop pushing me." This scene leads to the antagonist again pushing the author, "calling [the author] names," and insulting his mother. Finally, there is violence, with both youths hitting each other and the author getting the upper hand by kicking the other party as he falls down. As in $44 \%(N=64)$ of the action tales in our data set, this story's dramatic tension finally resolves through physical fighting, but not as a first response. It is only after an attempted conciliation that fighting occurs.

In Story 2 the female author takes us in a slightly different direction within the action tale style by explicitly referring to other youths who fan the fires of conflict by spreading innuendos about her:

Story 2

I know this girl who used to be my best friend, her name is Jennifer. Last year, me and Jennifer were inseparable, until this girl Lori told me that Jennifer was saying shit about me and my other friends when we weren't around. Normally, I wouldn't have taken this information any farther because I'm not someone who gets involved in hear say and gossip, but Lori was pretty quiet (the shy type) and I knew Jennifer and Lori were pretty close. So I confronted Jennifer, of course she denied it. I didn't know what to do or who to trust so I decided to discontinue both relationships. It's not something I wanted to do, it's something I had to do. [206]

Story 2 illustrates the principal role of rumor in youth conflict, as a vehicle for circulating information harmful to one's reputation ("talking about me and my other friends when we weren't around") and as a means for precipitating action against offending parties ("this girl Lori told me"). The story unfolds in the typically linear plot of most action tales, with two digressive moments: The first occurs when the author states that she does not typically become involved in "hear say and gossip," but that the close relationship between her two friends suggests the credibility of the allegations, which in turn prompts our intrepid author to confront her former friend. The dramatic tension in this story is resolved when the author avoids both of her friends be- 
cause of a lack of trust. The second digressive moment occurs at the end of the story, when the author states that she did not "want" to "discontinue" the relationships but "had to do so." Here, we see a hallmark of the action tale-the author's reference to unstated expectations about trust and friendship that compel her to act in a particular way regardless of her volition. Because Jennifer and Lori cannot be trusted, it is not possible to be friends with them, hence the avoidance. In this sense, we see how her responses in the story constitute what it means to be a friend in the local context. The story also demonstrates and upholds what it means to be relationally competent (i.e., to maintain friendships only with people who can be trusted).

Both Stories 1 and 2 illustrate how conflict constitutes and dramatizes assumptions about interpersonal relationships among peers. In Story 3, we see yet another aspect of action tales as the male author illustrates localized male expectations about gender roles and how images drawn from adult-controlled popular media influence local representations of youth conflict:

Story 3

When I was in the seventh grade this kid named Donald always bothered me, he always made fun of me and called me names. One day on the bus he said something that pissed me off big time, I don't really remember what it was but it had something to do with my hair. Since a girl I liked was watching I said "What's up then" and since he liked the same girl he said lets go after we get off the bus, so I said fine. When we got off the bus neither of us wanted to fight so I just stood there and he walked away. Then I noticed that the girl was watching so I said "that's what I though you faggot-yeah you better walk away" and I went home. After I finished my homework I decided to go outside. While I was outside I ran into Donald again, he said what's up and I said shut up so he said I'm sick of you lets go, and since my girlfriend was watching I decided to take off my shirt and fight like those ninjas in Bloodsport. I totally got beat down in front of everyone and even worse Donald made fun of me everyday until I fought him again, but the second time I won. [333]

The author provides a historical context for the story and also indicates that the narrated incidents were embedded in a series of altercations with "Donald." But the story displays the same ambiguous time frame as many action tales when its dramatic tension begins with a series of vague affronts by Donald ("something to do with hair") while the author is riding a school bus. The author notes that the comments made him angry ("pissed . . . big time") and then alludes to a key aspect of the story by noting that he responded to Donald because "a girl [he] liked was watching." As in Story 1 , the author of this story first 
takes a detour from physical violence, as neither protagonist "wanted to fight" upon leaving the school bus. Indeed, the original offending party "walks away." Presumably at a later point in the same day, the story continues outside the author's home with the predictable sequencing of an action tale, moving from verbal confrontation to physical altercation.

Story 3 displays three notable elements. First, the author inscribes traditional masculine and feminine roles in the story. $\mathrm{He}$ mentions that "the girl [he likes]" is watching the fight unfold outside his house, yet only four lines later he notes that "his girlfriend is watching." Throughout the story, his representation clearly underscores the importance of performing a role as a boy with bravado and courage who does not back down from a fight while a girl (especially a girlfriend) is watching. The author also illustrates common roles for girls represented in many of the action tales written by boys: as objects of attention or as bystanders outside of the main action sequences. Second, to galvanize his identity, the author draws images ("take off my shirt and fight like those ninjas in Bloodsport") from a film that centers on a secret competition for the world championship of martial arts. Bloodsport and its sequels, made and distributed by a Hong Kong media conglomerate, are popular among American adolescent boys and have spawned several action-video games. Third, the writer ends his tale with a sequence also seemingly taken from Bloodsport and many other martial arts movies. In these movies, the hero is sometimes bested in a fight and perhaps publicly humiliated (usually through trickery) during the opening scenes, only to redeem himself by besting his principal adversary at the movie's climax. In Story 3, our author does much of the same thing by suffering an initial, humiliating public beating ("got beat down in front of everyone"), after which "Donald made fun of me everyday." Our valiant author, however, eventually gains the upper hand by winning his fight with Donald on another occasion. How the author imagines conflict resolution, therefore, is in part structured by adult media just as it is firmly embedded in local expectations and routines.

Story 4 illustrates very different expectations for girls' roles in conflict, and conflict management from the perspective of a female author:

Story 4

One time on the bus this girl I new thought I said something to her and her sister and the girl were yelling at me and I yelling back. After the bus stopped and we got off, the girl attacked me and we started to fight. Before all of this the girl was always yelling for no reason. Anyway, then the bus driver got off and she let go of me and I just walked off my own way. I told my mom and she called the school and told what happened. I 
wasn't scared that much but I was afraid that we might fight again. The next day the girl and I got a big speech, and we never spoke to each other again.

Trouble begins in Story 4 with a disruption of the typical routine on a school bus, following a series of "yelling" incidents for "no reason." The author tells about how a fight erupted between her and a provocateur, which in turn led to the bus driver's intervention to restore the peace. The fight ends with the author walking "off [her] own way" and presumably her adversary doing the same. The next day, both the author and her opponent are sanctioned in the form of a "speech," and the two protagonists never "speak to each other again." Throughout Story 4, the female protagonists operate in much the same way as male protagonists do in male-authored action tales (as illustrated in Stories 1 and 3). In female-authored action tales, girls do not passively sit on the sidelines as objects over which to be fought; they are active participants at the core of peer conflict. Seen in this light, femaleauthored action tales implicitly speak back to the traditional expectations for girls contained in male-authored action tales. At the same time, female authors use some of the same premises to construct their tales as male authors do in their action tales.

Just as in male-authored action tales, for example, the dramatic tension in a female-authored action tale begins with a disruption of an everyday routine (e.g., riding the bus in Story 4). Female authors, like their male counterparts, also present fighting as a matter-of-fact part of the repertoire of peer conflict. More so than the male authors, however, female authors are likely to include a significant role for adults in their action tales. These roles typically involve third-party peacemaking of some kind (as illustrated by the bus driver's behavior in Story 4) or some kind of post hoc social control by a teacher or administrator (illustrated at the end of Story 4).

In our final action tale, Story 5 , the male author intertwines interpersonal relations with expectations associated with gender and ethnic categories:

Story 5

Well it started the day before I was walking my girlfriend to her class and already there was a problem with the blacks and Mexicans. I pushed the double doors open for my girl when this boy which happened to be mexican bump into me. I told him to watch where he is going and he said "Fuck You," I turned back around said "What up? What you want to do?" My girlfriend pulled me away and told me to forget about it. I did just for the rest of the day until the next day. I told my homeboys that I was going to get him. When the bus arrived to the school I gathered all of my homies and walked to the front where all the Mexicans kicked at and I yelled out "Whats up Now," then I was 
in his face. My girlfriend ran and jumped in front of me trying to stop us from fighting. He push her and like a chain reaction we fell I jumped and just started swing. [003]

The story opens with a short preamble about background tensions between "blacks" and "Mexicans" that serves as a backdrop to explain the meaning of a subsequent altercation and the author's mobilization of supporters. Against this backdrop, the author automatically understands a "bump" at the hands of a "mexican" as he escorts his "girlfriend" to class as a provocation. The bump escalates into a verbal confrontation through profanities ("Fuck You") and aggressive challenges ("What up? What you want to do?"). Just before a fight erupts, the author's girlfriend intercedes as a peacemaker to "pull" him away from the fracas. The author continues the conflict by proclaiming to his supporters ("homeboys") that "he is going to get him [the Mexican who bumped him]" and then gathers supporters to confront the "Mexicans" where they "kick at" (hang out). Before the confrontation escalates beyond strong words, the author's girlfriend intervenes again to try to prevent a fight, which ends in "a chain reaction," out of which the author "started swinging." This somewhat ambiguous ending, without a definitive winner or resolution, leaves the impression of on-going hostilities between the two protagonists, in part compelled and shaped by the unstated premises of challenge and riposte between ethnic groups at New West High.

Based on the description in Story 5 , there appears to be some form of collective liability in operation based on ethnic identification, such that an altercation between two members of different groups becomes the collective business of each group. In these kinds of contexts, individuals are not only able but are expected to mobilize supporters to pursue their disputes (Koch 1984; Gould 1999). We also see another role played by girls in male-authored action tales-as peacemakers, who swoop in to protect their "man" just prior to a physical fight. What is striking about the author's telling is that he never questions or laments his girlfriend's interventions. It is as if such action is embedded into the very role of what it means to be a "girlfriend" from the perspective of boys in the local context.

In all five of our exemplar action tales, the authors write about their behavior and that of other characters in a fashion resonant with the theoretical tales spun by cognitive sociologists (Cicourel 1974) and neoinstitutional theorists (DiMaggio \& Powell 1991). There is a preconscious, semiautomatic nature to the reasoning in an action tale that suggests practical action, rather than calculative or explicitly rule-based behavior. Whether drawing their cognitive models for action from local peer cultures, social expectations of masculine and feminine roles, or adult-produced cultural forms (e.g., "action" films such as Bloodsport, 
which evoke another sense of the term "action"), the authors of action tales emphasize "the way things are" (especially personal relationships and peer conflict) and the way "conflict is to be handled" among peers. In their stories, conflict is a core mechanism by which assumptions about interpersonal relations are constituted, enacted, and sometimes tacitly challenged.

\section{Moral Tales}

The authors of moral tales $(20 \% ; N=51)$ shift their focal perspectives from cognitive assumptions to prescriptive normative commitments whose violations mark dramatic tensions. Rather than accessing tacit assumptions about conflict and peer relations, the writers of moral tales explicitly tell about their moral reasoning, often referring to how normative commitments shape their decisionmaking and push conflict management away from violence to various forms of conciliatory talk or avoidance. Only 14 moral tales (27\%) contain instances of physical fighting. In moral tales, students discuss the harm that conflict can cause friends (e.g., "friends shouldn't do that to friends") in ways resonant with Gilligan's (1982) concept of "care" morality in social relationships. In other moral tales, writers emphasize principles of fairness and justice, again consistent with Gilligan's (1988) research on adolescent moral reasoning, and perhaps linked to a nascent sense of conventional, adult legality. ${ }^{23}$ The author of Story 6 mixes these perspectives in her narrative:

Story 6

Just the other week I had an conflict. I was in the hallway when Tom came up to me and was all in my face talking stuff to me. Okay the day before that I found a letter that said something about Tom and another girl having a relationship. So I went back and told Jennifer that I found a letter and it said something about Her boyfriend (Tom) and another girl, which I didn't know her name, had a relationship going on. I had to tell her because she is my friend and I don't want her to get hurt. So somehow Tom found out that I told Jennifer and was really mad at me. He called me some names that hurt me really bad. And he was trying to fight me, so I just walk away. I started crying after that, he hurt my feelings really bad. Me and Tom would say hi to each other now and then, and so I thought he was a real nice guy. I was wrong. After that my other friend Tina told Jennifer that Tom came all in my face. Jennifer was mad. She told Tom he had no right to do that even if it was true or

23 Our labeling of justice and fairness as a "nascent sense of adult legality" is not intended to imply that justice perspectives are more "mature" or developed than care perspectives. As Gilligan and associates (1988) have forcefully argued, neither justice nor care perspectives should be valorized above the other. Each have utility in moral reasoning and conflict management. 
not. Tom said he don't care, and when he see's me he's going to talk stuff to me. I was scared to go to school. I was thinking what if he hits me, what will happen? Well I've seen him, but he hasn't said anything to me. So I don't know if he really meant what he said. I know I shouldn't of got into their business but Jennifer is my friend. Friends help each other out. [251]

Similar to an action tale, the dramatic tension in this story begins with another student ("Tom") "talking stuff" to the female author. Unlike the linear plot of an action tale, however, the author quickly digresses from the action at hand by telling why Tom was "in [her] face." The altercation stems from the author passing information to Tom's girlfriend (Jennifer, who is also the author's friend) about Tom seeing "another girl." The altercation between Tom and the author occurs because he "found out that [the author] told Jennifer" about the affair. Mid-story, we encounter an example of "justice" morality in the characterization of Jennifer's reaction to Tom's confrontation with the author. Jennifer confronts Tom, so the author tells us, to admonish him that "he had no right to [confront the author] even if it [the author's passing the information about Tom to Jennifer] was true or not." At issue from Jennifer's perspective is the fairness and legitimacy of Tom's treatment of the author, rather than the explicit harm he did to the author by aggressively confronting her. In response to Jennifer, Tom "don't care" about what he did to the author and is willing to pursue the conflict further by "talk [ing] stuff" to the author at school.

If harm is not uppermost in Jennifer's or Tom's mind, it is quite salient in the author's representation of this conflict, and it is harm that involves not only damaging a personal tie but also potential violence. Just before the author ends the story, we learn that she is afraid that Tom might "hit" her, but that nothing has occurred yet. We do not learn what constrains Tom-an explicit norm, perhaps Jennifer's disapproval, or the author's avoidance-but we do learn what the author learned from her experience. Like many moral tales, the author concludes her story with didactic lessons about interpersonal relations. In this story, the author states two potentially contradictory lessons: that friends should not pry into other friends' romantic relationships ("I know I shouldn't of got into their business. . ..") and "[f] riends help each other out."

Her explicit recognition of the tensions between what could be called an "interpersonal right to privacy" and an "obligation to help" friends reveals a complex moral imagination, again consistent with the sophistication demonstrated by adolescents in studies of moral development (e.g., Gilligan 1988). It also suggests the recognition of normative conflict between equally legitimate rules that lead in different directions. 
In Story 7, the care/justice dichotomy is less salient as the white female author writes about morality from an almost Kantian-like perspective by stating two nonviolent rules she adheres to in handling peer conflict:

Story 7

There was this one girl. She was really big, very homely looking, and she had a terrible personality but she was my ex boyfriends ex girlfriend and she was supposedly "carrying his child." Well, she "loved" him because he was her "Baby's Daddy" and he really liked me. One day, I was sitting in the hall talking to him and she walked by me 3 or 4 times and about the 4th time, she spit water on me. My shirt was as wet as a mouthful of water could make it and I was very upset. But I took a deep breath and told myself to stay calm, it was just some water. For a couple of weeks she would harass me and swear at me when I walked by when finally she confronted me, asking me if I had been talking stuff about her (I hadn't been). She just stepped up talking her little ebonics and saying how she was going to kill me if I didn't stay away from her Baby's daddy. Well, A) I don't fight, I can, and I WILL if I have to, but I won't start it. I will only defend myself. B) I will Never-ever-ever fight over a guy. As far as I was concerned, she could have him. So I let her know that I wasn't afraid of her and if she wanted to pound my face in, its all good but tomorrow, when she's expelled, she might not be the most able person herself. So, after our little dispute in the hall was broken up by a teacher she was rudely confronted by my sister. And because of the fact that she was afraid of my sister she stopped messing with me. Until recently. She said the only thing holding her back from fighting before was because she was pregnant, but after she had the baby, she was going to beat me up. One day she came into the hall again with her friends (she only came with her friends so she could look big-n-bad) and started telling me off and saying how she was going to plan a drive-by at my house so know it would be her. She said "I should just pop you right now!" and I said "You know what? Pop me!" and she swung toward my face but stopped millimeters from my nose. She noticed I didn't move or flinch, so she walked away. [138]

The tension in this story focuses on a romantic triangle in which the romance appears to be largely over, but friendship remains (between the author and the boy) and jealously abounds (aimed at the author by the boy's ex-girlfriend). Complicating matters are claims by the author's adversary that the boy in question is "her 'Baby's Daddy'." In the first half of the story, we learn that the author holds her adversary, who is "really big, very homely looking ... . [with] a terrible personality" in disdain and that she harbors what appear to be racist sentiments toward her being an African American ("talking her little ebonics"). Once again, "talking stuff" (spreading rumors) and several provoca- 
tions involving profanity, spitting water, and violent threats ("going to kill me if I didn't stay away from her Baby's daddy") mark the dramatic tension in the story.

Mid-story, the author states the two rules that guide her actions in this incident and every incident regarding peer conflict. She first states that she doesn't fight unless it is to "defend [herself]" and then that she "Never-ever-ever fight[s] over a guy." The first of these norms codifies a pattern implicit in nearly all of the narratives regarding the inappropriateness of proaction in conflict. One "ought" to defend one's self, but should not seek out trouble. The second rule is intriguing because of its gender implications, particularly how it de-valorizes boys as objects to fight over. This is a quite different orientation than what we encountered in Story 4, where the female author took for granted the necessity of fighting when faced with an "attacker," or in Story 5, when the male author touched upon his assumptions regarding how fighting increases a boy's status in the presence of girls. The rules in Story 7 also reinforce the author's sense to push away from a violent altercation, undergird her resolve to "let [her adversary] know that [the author] wasn't afraid of her," and facilitate the space for two other factors that militate against the dispute escalating beyond verbal to physical confrontation: a teacher intervenes at one point into the dispute, and the author's sister aggressively confronts her sister's adversary.

The end of the story draws on two imageries-of gangs and of what could be called the "principled stand" against intimidation. As the story winds down, the author writes about a final confrontation in which her adversary states she "was going to plan a drive-by [shooting] at my house so know it would be her" and that "[she] should just pop you [shoot the author] right now." The author unflinchingly meets these threats by stating, "Pop me," as if to let her opponent know that she would not retaliate (and break her personal normative commitments) no matter what befell her. An angry fist is pulled back at the last instance, and our author emerges unscathed with her principles and face intact.

The "categorical imperatives" written about in Story 7 resulted in a final, "principled stand" against violence. In Story 8, the opposite occurs. A principled stand leads to violence:

Story 8

I was in 8th grade and got into a fight because I wasn't allowed into the basketball game. I was being harassed by the captains that wouldn't pick me and also many of the players. The same type of things had happened almost every day where they called me bad words so I decided to teach the ring leader a lesson. I've never been in a fight before but I realized that sometimes you have to make a stand against the people that constantly 
hurt you, especially emotionally. I hit him in the face a couple of times and I got respect I finally deserved. It was worth 3 day ISS [In-School Suspension] to finally teach that bully a lesson. I never have wanted to hurt someone that bad on impulse. I almost wanted to kill him for all the humiliation he'd caused me over those last 3 years. I proud of my stand because it was out of conviction and a lot of thinking, not just impulse. Killing him was only a thought and would never have killed him, I have a very strong moral sense. [352]

Story 8's author takes us back to his final year of junior high to tell us about a conflict on a basketball court. Once again, our author is not the initiator of conflict, but responds to normative violations committed against him as he was "harassed" by the two "captains" and "many of the players" of teams choosing up sides who "called [him] bad words." Later in the story we find out that the harassment has occurred over a three-year period and that his chief tormentor holds a status as a "bully." The author digresses from the stream of events to note that he had "never been in a fight," yet "sometimes you have to make a stand against the people that constantly hurt you, especially emotionally." The author hits the bully twice, which in turn brings him the "respect [he] finally deserved."

The conclusion of this story is particularly interesting because the author explicitly writes that his violence did not result from "impulse," (i.e., raw emotion), but out of "conviction" and "a lot of thinking" - a kind of "principled violence." Yet, he also notes in a coda at the end of the piece that although he harbored thoughts about "killing" the bully, he would never do so because he has "a very strong moral sense." The author implicitly recognizes how normative commitments cut both ways: They can motivate violence, as in a culture of honor in which defending one's self through physical combat is key to what Pitt-Rivers (1965:21) argues is "the value of a person in his own eyes [and] also in the eyes of society." But normative commitments also set limits and, in one sense, codify violence by demanding how much of it "should" occur in response to attacks upon one's social identity and how much would be beyond the pale. At least from the author's perspective in Story 8, his principled violence fell within appropriate boundaries and resulted in elevating him in the eyes of his peers.

The authors of moral tales demonstrate various kinds of moral reasoning in their narratives, some of which, as we noted previously, resonate with Gilligan's (1988) concepts of care and justice. Other moral narratives suggest rigid rule-orientations (e.g., Conley \& O'Barr 1990), which in the minds of authors take on the weight of law-like mandates that they heroically maintain even in the face of grave danger. Finally, we see that youthful morality does not always lead to peace through peaceful means, 
but, as among adults, can lead to "justified" violence, in which the victor looks back with pride and satisfaction at what he or she has accomplished through force.

\section{Expressive Tales}

Expressive tales (14\%; $N=35$ ) depart from the "cool cognition" (Suchman \& Edelman 1996) of action tales and the prescriptive norms evinced in moral tales. In these stories, authors reach back to understand, as much as possible within discursive limitations, the lived experience (Denzin 1990) and sensuality of emotion (Katz 1999), such as how "anger took them over" or how particular events generated a "hatred" for their peers. In this way, the authors of expressive tales treat emotions, as Nussbaum (1995:56) puts it, like "gusts of wind or the swelling currents of the sea ... push[ing] the agent around." Explicit references to norms, taken-for-granted assumptions, or rational decisionmaking are ancillary to the emotional fulcrum in expressive tales. These narratives can be fragmented as students "spit" out their story. Conflict emerges from emotional buildups that "burn" and are resolved via cathartic outbursts. Physical fighting appears in $49 \%(N=17)$ of the stories we identified as expressive tales, sometimes accompanied by the author's guilt, or simply bewilderment at what his or her emotions have wrought. Story 9's female author writes about an emotionally charged day in middle school that ends with unexpected relational consequences for the parties at New West High:

\section{Story 9}

At school one day I miss the bus and came late when I got their it was a problem with our group and the other group and I was just put in all of a sudden. As a girl wanting to fight me we all ready didn't like each other so it got real bad cause I was tired Haven't been taking my temper pills haven't been able to control my temper it got me so mad they started it but they ran to the principal so I went to my class so mad that I couldn't breathe asthma pump wasn't working then they called us all out the class room took us to a class room stayed \& 2 class periods other for me to cool down the girl that started in my group was like she don't know how other people got in it! That made me more mad they kept me in their all day and walked me to my bus. We still didn't like each other the whole eight grade but now we talk. Now we just got classes together started talking!! [303]

A quick read of Story 9 indicates that it is somewhat fragmented; it is difficult to clearly grasp the sequence of events leading up to and including the conflict, due in part to a lack of punctuation, but also due to its cathartic nature. As best as can 
be discerned, the dramatic tension in Story 9 evolves out of the author being unexpectedly placed in a group with a girl "wanting to fight me we all ready didn't like each other," which suggests the emotional buildup typical of expressive tales. Exacerbating this buildup is the author being "tired" and not "taking [her] temper pills." She notes she hasn't "been able to control [her] temper [and that the situation] got [her] so mad" that it resulted in her going to class "so mad that [she] couldn't breathe." Here, the reference appears to be some sort of mental health or behavioral problem for which the author is being treated. At this point, we do not learn exactly what happened between the author and the girl, although presumably a fight or verbal confrontation led to significant adult intervention and caused the author to take "2 class periods ... to cool down." As the story ends, the author tells us that it "made [her] more mad" when her adversary would not admit her responsibility in the fracas. The animosity and dislike between the two protagonists in this story continue throughout their last year at middle school. At the time the story was written, however, the two, long-time adversaries appear to be constructing a friendship, as the author and her adversary share classes at New West and have "started talking!!"

What is most significant about Story 9 (and expressive tales more commonly) is the sense that the author, in writing the story, has finally had a chance to "tell her story" about the emotions she experienced in the trouble represented. Negative, intense feelings in conflict handling, especially anger, are generally regarded by teachers and other personnel at New West as "emotional deviance" (Thoits 1990), in the sense that such feelings are believed to be largely inappropriate and dangerous. At the same time, the authors of expressive tales recognize that conflict management involves more than reasoned discussion; it also involves the recognition and handling of negative feelings as significant elements of conflict management. Moreover, one could speculate whether the nascent personal relations between the author and her adversary would be possible without the "emotional energy" (Collins 1975) generated from conflict. Here again, we see how conflict, as represented in student narratives, operates as a core mechanism that both disrupts and reconstructs interpersonal relations among youth.

Story 10 illustrates another side of the experience of intense emotions during peer conflict away from New West, in the author's grandparent's home:

Story 10

The conflict started when my cousins started ragging on me at my grandmas house. They always teased me because I am always doing something different from them and they never stop. 
For a while it didn't bother me because I didn't really care very much for what they said. Because I was not to fight or argue. But one day when I was visiting their I wasn't having a very good day and, I did something to make them start Ragging on me. They were laughing and making fun of me I was getting really steamed up. and I have never felt like this before, but I got a weird urge to hit them. I did but it wasn't out of anger it was out of love, because I love them so much that I wanted them to stop teasing me and others I didn't feel very good after that I threw up because I hate fighting people out of anger. But I will if I have to. [213]

Story 10 begins with the male author's emotional buildup in the face of his cousins' teasing. ("They always teased me . . . and they never stop.") The author refers to a household rule (presumably installed by his parents) that he "was not to fight or argue," which helps him manage his feelings about being teased. On a particular "bad" day, however, our author unintentionally provokes his cousins and they "start Ragging on [him]." (The capitalization of "Ragging" was exaggerated in the original, which suggests particularly intense teasing.) His tormentors make a bad situation worse by "laughing and making fun" of the author, which "really steam [s] [him] up." The intriguing part of the story occurs in the final few lines, where the author writes about his reaction to his cousins. He "[feels] a weird urge to hit" his cousins and attributes this urge not "out of anger" but "out of love, because [he] love [d] them so much that [he] wanted them to stop teasing [him]." He admits to hitting his cousins, and then notes that he "didn't feel very good after" the altercation, to the point of becoming physically ill over it. ("I threw up.") The story ends by reversing the earlier attribution for the fight from love to "anger" in a way that suggests self-admonition for emotionally motivated fighting. ("I hate fighting people out of anger.") Simultaneously, the writer attempts to legitimize his emotion and violence with a coda about taking a principled stand similar to those contained in Stories 7 and 8. ("But I will if I have to.")

Stories 9 and 10 both point toward emotions as a "site" of social control in schools (Boler 1999) and the cultivation in students of non-emotional discourse in conflict management. In Story 9, this theme emerges from the author's recounting of adult reactions and social control directed at her throughout her emotion-laden conflict. Story 10 addresses another angle of this theme when the author flatly states his disgust over his own emotionally fueled fighting. These stories, then, illustrate another subtle way that adult discourse and institutions figure in peer conflict by controlling, conditioning, and even banishing strong, negative emotional discourse from conflict management. Our last narrative style encompasses what many students consider to be the flip side of the expressive tale: the rational tale. 


\section{Rational Tales}

Rational tales are the least-prevalent style in our data set $(9 \%$; $N=24$ ). In this type of story, the author represents conflict as a dramatic tension that, similar to moral tales, arises from an explicit normative violation embedded in everyday peer relations. As the drama unfolds, the author rationally "weighs" his or her options to resolve the tension, including the possible material and/or symbolic consequences of various behaviors. Norms, taken-for-granted assumptions, and emotion can all play a part in a rational tale, but the author evaluates them in a calculative, consequentialist fashion (e.g., "Should I follow this norm or not, given the consequences?") through narrative digressions embedded in the sequence of events that compose the story. Although authors of rational tales consider fighting as a means to resolve conflict, they typically do not include physical violence in their stories (only seven rational tales contain a fight), but instead represent intimidation, conciliatory talk, or avoidance, or they write about forgetting (lumping) the matter. A coda often appears at the end of a rational tale, which beckons toward the author's future, either in terms of his or her personal outlook and behavior or to the relationship between themselves and their adversaries. Story 11 exhibits many of these tendencies as the author writes about an altercation that occurred close to the time of our narrative survey:

Story 11

My conflict was a week ago. I had a conflict because the guy was flirting with my girlfriend. He knew we were going out, so I got upset and went up to him and talked to him face to face we were yelling back and forth. The thing that was going through my mind was that if we fight I'm going to be in I.S.S. [In School Suspension], but I would get my respect. If I didn't fight I would loose respect and I would get laugh at, and other things were running through my mind like, I'm not going to fight over no female. and what if I got beat up. But after all that he walked away and he called me a "playa hata" [player hater] so I push him and he kept on walking. Later on he came back and apologize for disrespecting me. After words I felt kind of bad because he was scared of me. [156]

The dramatic tension in this story revolves around another peer "flirting" with the author's "girlfriend," which leads to a verbal confrontation between the two students. Plot digressions about various options and their potential costs and benefits begin almost as soon as the story itself begins. The author, for example, realizes that if he fights the flirt, he might end up suspended, yet the fight could earn him "respect," unless he lost, in which case he would be "laugh [ed] at." He also weighs the value 
of fighting over a girl and the deleterious consequences should he lose the fight. None of these possibilities occurs as the boys push each other, after the author's adversary calls him a derogatory name, "playa hata." The term refers to a peer, typically female, who disdains boys ("players") who simultaneously date several girls. In this context, the phrase is intended to cast aspersions on the author's masculinity. ${ }^{24}$ The story ends with the author's adversary apologizing to him out of fear, or so the author believes. The last line of the story is a bit unexpected: The author expresses some remorse about scaring his adversary.

Story 11 presents an aspect of "respect" among peers that differs from treatments in moral tales. Recall that Story 8's author wrote about taking a "stand" and earning respect as a principled outcome of his deliberation about what was the right thing to do in a conflict. Story 11's author, by contrast, addresses respect from an instrumental stance in which it is a form of "symbolic capital" (Bourdieu \& Passeron 1977) to be gained or lost via peer conflict. ${ }^{25}$

Symbolic capital, aside from its relationship to resources, also carries a deterrence aspect that implicitly appears in Story 11 . Early on in the story, the author notes that his adversary flirted with his girlfriend, with full knowledge of the author's relationship with the girl. This representation suggests that the flirt's behavior occurred as a reflective choice, with full information about the situation. Such flirtatious behavior itself reflects the author's sense of loss of symbolic capital because his right to respect was not lofty enough to deter the transgression. Deterrence also appears at the end of the story, when the author notes that his adversary feared him. The fact that the author writes that his adversary apologized to him for "disrespecting" him, rather than for the altercation itself or for specifically flirting with the girlfriend, indicates that the author's status as a person of worth played a role in motivating the apology and in cultivating the author as someone to fear.

\section{Summary and Discussion}

The conflict narratives in this study suggest that the consciousness of conflict among youths-like that among adults-is not a singular entity, but comprises a rich and diverse range of perspectives. Whether writing about fending off advances to

24 Our ethnographic data indicate that the term is of African-American origin and is pronounced in an exaggerated, "Brooklyn style" accent.

25 The accumulation of symbolic capital marks a student as worthy of respect among peers and leads to other advantages (e.g., favored access to particular pools of girlfriends or boyfriends) and resources in conflict that enable the further accumulation of symbolic capital (e.g., ease of access to powerful supporters). Students who represent conflict via rational tales thus envision themselves as competitors in peer "markets" of symbolic capital at New West High. 
one's girlfriend, taking a principled stand in the face of peer harassment, or navigating ethnic tensions while pursuing interpersonal grievances, youths embed conflict and its management in the everyday assumptions, explicit rules, emotions, and rational choices that enable and constrain peer relations. Their stories exhibit decisionmaking that underscores the intuitive side of conflict in action tales, principled stands in moral tales, the sensualness of conflict in expressive tales, and calculative choices in rational tales. The authors' representations of their conflict management strategies in many ways mirror those found among adults. Conciliatory talk, avoidance, lumping, third-party peacemaking and partisanship, and verbal intimidation all appear in the narratives written by New West High students.

Violence also appears in the narratives and is addressed in many ways. The students in our exemplars represent violence in the context of emotional outbursts and as quasi-automatic responses to uphold social identities, perform role expectations, and maintain relational competencies. They also represent violence as more self-consciously controlled-as principled and instrumental behavior that emerges from reflective, deliberative thinking about respect and status vis-à-vis other peers. The narratives thus suggest that part of what it means to be a competent youth in the local context is to understand and speak the language of violence. In this way, violence becomes a cultural idiom and means of expression among many youth. However, to understand a language does not mean that every youth speaks it. Nor does it mean that every youth engages in violence.

At the margins of the youth conflict narratives, adults intervene occasionally to separate disputants once a conflict is underway, and even more occasionally to intervene to prevent conflicts from escalating beyond verbal confrontations to physical violence. But if adults are explicitly absent from most of the narratives in this study, adult discourses and institutions are implicated in nearly all of them. We encountered images from adult-controlled media and explicit norms set down by adults. We also suggested that the treatment of emotion by our student authors is tied to adult preferences for rational discourse (and the repression of emotion) in conflict management. Table 1 concisely summarizes our findings with respect to each narrative style.

Despite the tacit footprints of adult discourse and institutions throughout our data, we found little evidence of legality in the narratives (save for the rigid rule-orientations found in some of the moral tales). Some of the absence of legality may be artifactual: We did not ask students to write about conflict with teachers or other adult authorities where rights talk or legal orientations could be more salient than among peers. We suspect that this finding, as tentative as it is, suggests a fruitful direction for future research. We return to this possibility at the conclusion of this 
Table 1. Summary Comparison of Youth Narratives*

\begin{tabular}{|c|c|c|c|c|}
\hline Representation of & $\begin{array}{l}\text { Action Tales } \\
(N=144)\end{array}$ & $\begin{array}{l}\text { Moral Tales } \\
(N=51)\end{array}$ & $\begin{array}{c}\text { Expressive Tales } \\
(N=35)\end{array}$ & $\begin{array}{c}\text { Rational Tales } \\
\quad(N=\mathbf{2 4})\end{array}$ \\
\hline $\begin{array}{l}\text { Bases of everyday } \\
\text { conflict }\end{array}$ & $\begin{array}{l}\text { disruption of } \\
\text { everyday } \\
\text { routines \& } \\
\text { expectations }\end{array}$ & $\begin{array}{l}\text { normative } \\
\text { violation }\end{array}$ & $\begin{array}{l}\text { emotional } \\
\text { provocation }\end{array}$ & goal obstruction \\
\hline Decisionmaking & intuitive & principled stand & sensual & calculative choice \\
\hline Conflict handling & confrontational & ritualistic & cathartic & deliberative \\
\hline Physical violence† & in $44 \%(N=67)$ & in $27 \%(N=16)$ & in $49 \%(N=20)$ & in $29 \%(N=7)$ \\
\hline $\begin{array}{l}\text { Adults in youth } \\
\text { conflict }\end{array}$ & $\begin{array}{l}\text { invisible or } \\
\text { background }\end{array}$ & sources of rules & $\begin{array}{l}\text { agents of } \\
\text { repression }\end{array}$ & $\begin{array}{l}\text { institutions of } \\
\text { social control }\end{array}$ \\
\hline
\end{tabular}

article. Before we consider implications of our findings or questions for future research, however, we discuss potential explanations for the distribution of the conflict stories across the four narrative styles.

\section{Class Codes, Moral Development, and Political-Institutional Resistance}

We offer three alternative theoretical explanations for the predominance of action tales among our student authors: a class code explanation, a moral development explanation, and an institutional resistance explanation. The first of these explanations derives from Bernstein's (1964; 1975) work on social class and linguistic codes. Bernstein originally sought to understand how different class backgrounds and their associated linguistic "codes" constrained or enabled children's learning in school. In working-class (i.e., lower income) families, Bernstein claimed that children learn "restricted codes" that contain simple syntactic structures, narrow ranges of vocabulary, and high amounts of tacit knowledge about local social contexts. In middle- and upper-class families, he claimed children learn "elaborated codes" that exhibit complex syntactic structures, expansive vocabularies, and encourage communication through inclusion of explicit and more abstract information about social context. Bernstein concluded that working-class children are less likely to succeed academically because their indigenous language abilities are in tension with and ill-prepared to manage elaborated codes used in schools. Students from middle- and upper-class families, in contrast, come to school with indigenous communicative advantages that collectively enable them to more readily adapt and succeed in school.

From a class code perspective, one could argue that the action tale is a type of restricted code because it assumes more taken-for-granted assumptions and tacit knowledge about peer 
conflict, reasoning processes, and the social context at New West High than the three other narrative styles. Our reading of the narratives, however, suggests that the linguistic markers used by Bernstein to define restricted and elaborated codes do not systematically differentiate action tales from the other narrative styles in our data set. Even if such linguistic differences did exist, the class code explanation appears implausible at New West because the vast majority of the student authors in this study come from lower-income households. Thus, there seems insufficient class variation among students to generate systematic variation in narrative styles.

An alternative explanation for our findings can be found in the moral development literature, especially the works of Gilligan $(1982 ; 1988)$. From this perspective, the prevalence of action tales is a function of each individual student author's moral development. At the dawn of adolescence (12 to 15 years of age), Gilligan (1988) argues that youths begin to refine their interpretive schemes, becoming especially sensitive and self-reflective about the expectations and roles among their local peer cultures (see also Dornbusch 1989). Crucial in this refinement is the further development of the "self," not only as a moral decisionmaker that chooses between good and evil but as a "narrator of . . moral drama [that] chooses, consciously or unconsciously, where to stand, what signs to look for, and what voices to listen to in thinking about what is happening and what to do" (Gilligan 1988:xxiii).

It is not surprising, in light of these arguments, that the ninth grade student authors in our study wrote more action tales than the other narrative styles added together. As narrators of their own conflict dramas, their "selves" are submerged in the practical exigencies of navigating through local peer cultures, whose unstated role expectations and performances are manifested in the students' authorial voices. Yet, most authors, because of their ages, have not sufficiently developed their capacities to interpret their local contexts. As a result, they concentrate on taken-forgranted assumptions of their peer and wider cultures, rather than on more self-consciously reflective interpretation and evaluation. This argument would lead one to expect that older students at New West High (and other high schools) would be more likely than the younger students in our sample to organize their narratives around explicit and rich references to interpersonal norms and consequences, rational thinking, and emotional expression.

Perhaps the most speculative explanation for the prevalence of action tales among the student authors in this study derives from the political-institutional wing of youth cultural studies. Here, the argument would be that the prevalence of action tales is a manifestation of youth resistance to official educational dis- 
courses and institutions. Schools, to unpack this argument, are preeminently sites of social control that seek to fill up the "vessels" of youth with adult tastes and desires (Giroux 1996). The educated person, or more specifically, the educated youth, is the end result of this process and is not so much equipped to go out and appropriate the world with a set of cognitive skills as to be appropriated by adult capitalist institutions. Crucial in the production of educated youth are official discourses embedded in curriculums, classroom pedagogies, and naked exercises of authority. These official contexts demand that students learn to communicate appropriately, which means being facile in the use of various official discourses.

Seen in this light, action tales are students' own discourse, apart from official, institutionalized discourses that they learn in school. Action tales embody the expectations of local peer relations and the various images that youths appropriate for use in that culture from wider contexts. By contrast, rational tales derive from the rational discourse that dominates virtually all critical thinking and reasoning processes learned in school, as well as peer mediation and other techniques adults teach children and youth to manage conflict. Moral tales derive from the very disciplinary and authoritative fabric of schools. And the representation of emotions in expressive tales harkens to the social control and repression of emotion in most mainstream pedagogies (Boler 1999). Based on this perspective, we would expect students who are deeply embedded in official routines and discourses of school, as measured by their intense participation or leadership in officially initiated and sanctioned activities, to produce more rational, moral, and expressive tales (in which an underlying theme is the control of emotion) than action tales. Aside from these explanations and hypotheses, our findings point toward a variety of theoretical and policy implications.

\section{Theoretical and Policy Implications}

At a conceptual level, our study provides a way to think about decisionmaking and framing processes regarding youth conflict that complements and pushes the boundaries of traditional dichotomies of care and justice moralities found in the social psychology of adolescent development (Gilligan 1988). Rather than assuming that all young people's representations of conflict involve types of moral discourse, our typology suggests a wider range of reasoning processes that emphasize other aspects of cognition, such as practical action and rational-choice decisionmaking, as well as elements of emotion. ${ }^{26}$ Along the same lines,

26 Critical school researchers (e.g., Giroux 1996; Levinson 1998), for example, could use our work as a point of departure to expand their conceptualizations of youth resistance beyond moral and rights-based discourses. If narrative styles in part reflect the 
our typology may carry greater conceptual potential than current dichotomies (e.g., "rules vs. relationships"; Conley \& O'Barr 1990) for the kinds of reasoning processes all disputants, regardless of age, use in defining conflict, making decisions about how to handle conflict (including mobilizing law), and framing acceptable resolutions to it. As we noted in the main body of this article, each of the narrative styles used by our young authors links in some ways to major theoretical traditions in the social sciences. As a result, one strength of our approach is its ability to draw - within a broadly interpretivist framework-from a variety of theoretical perspectives to understand the lived experience of disputants and conflict.

The previous implication could also lead to a theoretical strategy for understanding particular articulations of youth and adult cultures in local contexts (Massey 1998). The implication here is a partial reconceptualization of youth and adult cultures as multiple, sometimes overlapping, sometimes conflicting, bundles of narratives that come to be intertwined in local contexts. From this perspective, we can begin to think of the building blocks of cultures as different narrative styles in which various aspects of reality are accentuated, constituted, or challenged, just as others are deemphasized or silenced.

In addition to theoretical implications, our work also points toward a policy implication for youth-centered conflict interventions. Narrative analysis has been used to analyze the structures and assumptions of specific policies and policy regimes (Roe 1994). It has not, however, been used in the service of policy implementation, which is key, as Pressman and Wildavsky (1984) remind us, to successful policy outcomes. Central in implementation is the local context and its "fit" with assumptions at the policy level, for it is on the local level that the actual work of a policy occurs, is redirected, and ultimately fails or succeeds. An important element of such contexts is what Geertz (1983) refers to as "local knowledge"-understanding the immediate perspectives and practices of actors in a given setting. Narrative analysis of the sort we have presented in this study could provide a strategy for systematically accessing student voices about youth conflict. By directly accessing student voices via conflict narratives, youths could more actively be involved with adults in the construction of conflict intervention programs (such as peer mediation), rather than have such programs overlaid on them (Lang et al. 1998).

realities of conflict among youths as they themselves see it, such styles may provide clues to how youths view political climates of schools. 


\section{Questions for Future Research}

In addition to the implications previously discussed, our research suggests a number of specific questions for future research. The first of these concerns the "social distribution" of narrative styles across ethnic, gender, and class lines (Morrill et al. 1998). In the current analysis, we scratched the surface of understanding how particular aspects of the narratives are gendered, how youths conceive and manage ethnic tensions in their representations of interpersonal conflict, and why action tales predominate in our data set. What we do not know is whether ethnic identification, gender, or class location is associated with particular narrative styles or whether and how particular narrative styles are used to constitute ethnic, gender, or class boundaries (e.g., Lamont 1992). Another aspect of the social distribution of narrative styles concerns social and political power, as noted before. A feature of contemporary narrative analysis in sociolegal research is its potential for revealing subversive or counterhegemonic narratives (Ewick \& Silbey 1995). Our study only begins to address these issues by speculating on whether the prevalence of action tales in our data set signals a kind of resistance to (or retreat from) official discourses and how differences in female representations of gender roles could be read as counterhegemonic to dominant male representations. Future research needs to address these issues in greater depth.

A second area for future research concerns how narrative styles are used in peer interaction. Our data set consists of what could be called "narratives of conflict" rather than "narratives in conflict." (On related perspectival differences, see Snow \& Anderson 1993.) The former type of narrative refers to stories about conflict that insiders produce for outsiders, whereas the latter refers to stories that are produced among insiders in the midst of conflict. Because we collected only narratives of conflict, we do not have a means, in the present study, to assess how the narratives we collected differ or overlap in terms of content and form with those that peers produce for themselves in social interaction. Nor can we assess the contestation among or functions of narratives that insiders interactively produce as they engage in peer conflict. Such inquiry would require both narrative and ethnographic analysis in a team approach that could collect narratives from multiple individuals and groups. Our larger field project at New West High ultimately may provide some leverage to answer these questions.

A third line of inquiry concerns the relationship between narratives and other forms of behavior. Although we agree with Ewick and Silbey (1995) that narratives in part constitute the reality of particular sociocultural contexts, we believe that other forms of behavior, such as conflict management itself, also consti- 
tute reality. Therefore, without slipping into a traditional attitude-behavior dichotomy (Deutscher 1966), we urge future research that can focus attention on how linguistic and other forms of behavior relate to one another. Such research, for example, might take a historical turn to see if dominant narrative styles at one point in time lead to subsequent forms of decisionmaking and outcomes among local players in a particular setting.

Yet another area of research takes us to macro questions regarding the sociopolitical legitimacy of different narrative styles; in particular, which styles have "institutional stickiness" in the sense that they become taken for granted and have the force of institutionalized norms. This issue again leads to cultural aspects of social power associated with specific narrative styles. An important question, therefore, is not only "Who gets to narrate whom?" (Cornell 1998) but also "How is one allowed to narrate?" In other words, what narrative styles are youths encouraged and discouraged to use? This question directly relates to our earlier speculations about the prevalence of action tales and wider arguments by Conley and O'Barr (1998) regarding the "legal adequacy" and legitimacy of conflict storytelling. It also relates, in a broadly theoretical sense, to Meyer and associates' (1997; see also, Dobbin 1994) work on the dominance of the "Western rational account" for collective and individual behavior in contemporary North American and European cultures. The Western rational account, with its emphasis on rationalistic decisionmaking and rationalized rules, provides the broad contours for the rational and moral tales written by the student authors in this study. Given this backdrop, do students who narrate their lived experiences of conflict as action or expressive tales unintendedly delegitimize their voices? Are students who narrate their conflicts as rational and moral tales more likely to receive greater credibility for their perspectives from adult authorities?

A final issue for future research focuses on the role of legality in young people's lives. As we noted earlier, recent sociolegal scholarship has painted a portrait of pervasive legality in the lives of American adults-so much so, that it is difficult to believe that any rule-oriented perspective is not an instance of legality (Ewick \& Silbey 1998). Despite some research to the contrary (e.g., Baumgartner 1988; Ellickson 1991), if we accept the pervasiveness of legality as a working hypothesis, it is striking that our student authors do not, for the most part, draw on legality in their conflict narratives. This finding suggests several questions for future research: When and how does legality become pervasive in the lives of young people? Is the development of legal consciousness a maturation process in which cognitive development naturally leads to the development of moral reasoning oriented around abstract rules, as Kohlberg (1981) argued? Or is legal consciousness conditioned by social location and access to the 
means of social power, including education and material resources, in American society? This last question brings us full circle to the first set of research questions imagined by our work on the social distribution of narrative styles. As with language and discourse, rule-orientations, including producing "legally adequate" storytelling, may be a function of social power rather than power-neutral maturation processes (Conley \& O'Barr 1998). The questions outlined here only begin to contemplate the research agenda suggested by this study. It is only by crossing disciplinary boundaries and combining narrative analysis with other methods capable of capturing the diversity of youth voices and experiences that we will be able to pursue this agenda. Such research, moreover, will bring us closer to a theoretically and empirically rich sociolegal understanding of conflict and law that not only offers insights into adult troubles, but youth conflict as well.

\section{References}

Abbot, Andrew (1992) "From Causes to Events: Notes on Narrative Positivism," 20 Sociological Methods $\mathcal{E} 0$ Research 428-55.

Acland, Charles R. (1995) Youth, Murder, Spectacle: The Culture Politics of "Youth in Crisis." Boulder, CO: Westview Press.

Adelman, Madelaine (1997) "Gender, Law, and Nation: The Politics of Domestic Violence in Israel." Ph.D. diss., Department of Anthropology, Duke University, Durham, NC.

Adler, Patricia A., \& Peter Adler (1998) Peer Power: Preadolescent Culture and Identity. New Brunswick, NJ: Rutgers Univ. Press.

Ainsworth, Janet (1991) "Re-Imagining Childhood and Reconstructing the Legal Order: The Case for Abolishing the Juvenile Court," 69 North Carolina Law Rev. 1083-1133.

Alderson, Priscilla (1995) Listening to Children: Children, Ethics, and Social Research. Ilford, England: Barnardo's.

Aries, Philippe (1962) Centuries of Childhood: A Social History of Family Life. New York: Knopf.

Aronowitz, Stanley, \& Henry Giroux (1993) Education Still under Siege. Westport, CT: Birgin \& Garvey.

Baumgartner, M. P. (1988) The Moral Order of a Suburb. New York: Oxford Univ. Press.

Becker, Howard S. (1963) Outsiders: Studies in the Sociology of Deviance. New York: Free Press.

Beckson, Karl, \& Arthur Ganz ([1960]/1999) Literary Terms: A Dictionary, 3d ed. New York: Farrar, Straus \& Giroux.

Bernstein, Basil (1964) "Elaborated and Restricted Codes: Their Social Origins and Some Consequences," 66 American Anthropologist (special issue) 55-69.

- (1975) Class, Codes, and Control. New York: Schocken Books:

Bing, Leon (1991) Do or Die. New York: Harper \& Row.

Black, Donald (1976) The Behavior of Law. New York: Academic Press.

_- (1983) "Crime as Social Control," 48 American Sociological Rev. 34-45.

(1990) "The Elementary Forms of Conflict Management," in the School of Justice Studies, Arizona State University, eds., New Directions in the Study of Justice, Law, and Social Control. New York: Plenum. 
Black, Donald, \& M. P. Baumgartner (1983) "Toward a Theory of the Third Party," in K. O. Boyum \& L. Mather, eds., Empirical Theories about Courts. New York: Longman.

Boler, Megan (1999) Feeling Power: Emotions and Education. New York: Routledge.

Bortner, M. A., \& Linda A. Williams (1997) Youth in Prison: We the People of Unit Four. New York: Routledge.

Bourdieu, Pierre, \& Jean-Claude Passeron (1977) Reproduction in Education, Society, and Culture. London: Sage.

Cicourel, Aaron V. (1974) Cognitive Sociology. New York: Free Press.

Cintron, Ralph (1997) Chero Ways, Gang Life, and Rhetorics of the Everyday. Boston: Beacon Press.

- (2000) "Listening to What the Streets Say: Vengeance as Ideology?" 567 The Annals of the American Academy of Political and Social Science (Volume on School Violence) 42-53.

Cloward, Richard, \& Lloyd Ohlin (1960) Delinquency and Opportunity: A Theory of Delinquent Gangs. Glencoe, IL: Free Press.

Cohen, Alfred K. (1955) Delinquent Boys: The Culture of the Gang. Glencoe, IL: Free Press.

Cohen, Phil (1972) "Subcultural Conflict and Working Class Community." Working Papers in Cultural Studies 2, University of Birmingham, Centre for Contemporary Cultural Studies, Birmingham, England.

Collins, Randall (1975) Conflict Sociology: Toward an Explanatory Science. New York: Academic Press.

Conley, John M., \& William M. O'Barr (1990) Rules Versus Relationships: The Ethnography of Legal Discourse. Chicago: Univ. of Chicago Press.

- (1998) Just Words: Law, Language, and Power. Chicago: Univ. of Chicago Press.

Cooney, Mark (1998) Warriors and Peacemakers. New York: New York Univ. Press.

Cornell, Stephen (1998) "That's the Story of Our Life: Ethnicity and Narrative, Rupture, and Power," in P. R. Spickard \& W. J. Burroughs, eds., We Are a People: Narrative and Multiplicity in the Construction of Ethnic Identity. Philadelphia: Temple Univ. Press.

Corsaro, William A., \& Donna Eder (1990) "Children's Peer Cultures," 16 Annual Rev. of Sociology 197-220.

Corsaro, William A, \& T. A. Rizzo (1990) "Disputes in the Peer Culture of American and Italian Nursery School Children," in A. D. Grimshaw, ed., Conflict Talk: Sociolinguistic Investigations of Arguments in Conversations. Cambridge, England: Cambridge Univ. Press.

Daly, Kathleen, \& Lisa Maher (1998) Criminology at the Crossroads: Feminist Readings in Crime and Justice. New York: Oxford Univ. Press.

Decker, Scott H., \& Barrik Van Winkle (1996) Life in the Gang: Family Friends and Violence. Cambridge, England: Cambridge Univ. Press.

Denzin, Norman (1990) "On Understanding Emotion: The Interpretive-Cultural Agenda," in T. D. Kemper, ed., Research Agendas in the Sociology of Emotions. Albany, NY: SUNY Press.

Deutscher, Irwin (1966) "Words and Deeds: Social Science and Social Policy," 3 Social Problems 235-54.

Devine, John (1996) Maximum Security: The Culture of Violence in Inner-City Schools. Chicago: Univ. of Chicago Press.

Dezalay, Yves, \& Bryant Garth (1996) Dealing in Virtue: International Commercial Arbitration and the Construction of the Transnational Legal Order. Chicago: Univ. of Chicago Press.

DiMaggio, Paul J., \& Walter W. Powell (1991) Introduction to W. W. Powell \& P. J. DiMaggio, eds., The New Institutionalism in Organizational Analysis. Chicago: Univ. of Chicago Press. 
Dobash, R. Emerson, \& Russel Dobash (1979) Violence Against Wives: A Case Against the Patriarchy. New York: Free Press.

Dobbin, Frank (1994) "Cultural Models of Organization: The Social Construction of Rational Organizing Models," in D. Crane, ed., The Sociology of Culture. Oxford, England: Blackwell.

Dornbusch, Sanford (1989) "The Sociology of Adolescence," 15 Annual Rev. of Sociology 233-259.

Durkheim, Emile (1933/1893) The Division of Labor in Society. New York: Free Press.

Dwyer, Claire (1998) "Contested Identities: Challenging Dominant Representations of Young British Muslim Women," in T. Skelton \&.G. Valentine, eds., Cool Places: Geographies of Youth Cultures. London: Routledge.

Eder, Donna (1995) School Talk: Gender and Adolescent Culture. New Brunswick, NJ: Rutgers Univ. Press.

Ellickson, Robert C. (1991) Order Without Law: How Neighbors Settle Disputes. Cambridge, MA: Harvard Univ. Press.

Engel, David M., \& Frank W. Munger (1996) "Rights, Remembrance, and the Reconciliation of Difference," 30 Law E' Society Rev. 7-54.

Epstein, Jonathan S. (1998) Youth Culture: Identity in a Postmodern World. Oxford, England: Blackwell.

Espeland, Wendy (1998) The Struggle for Water: Politics, Rationality, and Identity in the American Southwest. Chicago: Univ. of Chicago Press.

Ewick, Patricia, \& Susan S. Silbey (1995) "Subversive Stories and Hegemonic Tales: Toward a Sociology of Narrative," 29 Law E Society Rev. 197-226.

—_ (1998) The Common Place of Law: Stories from Everyday Life. Chicago: Univ. of Chicago Press.

Feld, Barry (1999) Bad Kids: Race and the Transformation of the Juvenile Court. New York: Oxford Univ. Press.

Felstiner, William L. F., Richard L. Abel \& Austin Sarat (1980-81) "The Emergence and Transformation of Disputes: Naming, Claiming, and Blaming . . ., 15 Law E' Society Rev. 631-54.

Fine, Michelle (1991) Framing Dropouts: Notes on the Politics of Urban Public High School. Albany, NY: SUNY Press.

Fine, Michelle, \& Lois Weis (1998) The Unknown City: The Lives of Poor and Working Class Young Adults. Boston: Beacon Press.

Fineman, Martha Albertson (1991) The Illusion of Equality: The Rhetoric and Reality of Divorce Reform. Chicago: Univ. of Chicago Press.

Gaines, Donna (1990) Teenage Wasteland: Suburbia's Dead End Kids. Chicago: Univ. of Chicago Press.

Geertz, Clifford (1983) Local Knowledge: Further Essays in Interpretive Anthropology. New York: Basic Books.

Gillespie, M. (1993) "Technology and Tradition-Audio-Visual Culture among South Asian Families in West London," in A. Gray \& J. McGuigan, eds., Studying Culture: An Introductory Reader. London: Edward Arnold.

Gilligan, Carol (1982) In a Different Voice: Psychological Theory and Women's Development. Cambridge, MA: Harvard Univ. Press.

- (1988) "Adolescent Development Reconsidered," in C. Gilligan, J. V. Ward, \& J. M. Taylor, eds., Mapping the Moral Domain. Cambridge, MA: Harvard Univ. Press.

Gilroy, Paul (1993) The Black Atlantic. Cambridge, MA: Harvard Univ. Press.

Giroux, Henry (1996) Fugitive Cultures: Race, Violence, and Youth. London: Routledge.

- (1998) Channel Surfing: Racism, the Media, and the Destruction of Today's Youth. New York: Griffin Trade Paperback.

Gluckman, Max (1955) Crime and Custom in Africa. Glencoe, IL: Free Press.

Goffman, Erving (1963) Stigma: Notes on the Management of a Spoiled Identity. New York: Simon \& Schuster. 
(1974) Frame Analysis. New York: Harper \& Row.

Gottfredson, Michael, \& Travis Hirschi (1990) A General Theory of Crime. Stanford, CA: Stanford Univ. Press.

Gould, Roger V. (1999) "Collective Violence and Group Solidarity in Corsica," 64 American Sociological Rev. 356-80.

Griffin, C. (1985) Typical Girls? Young Women from School to Job Market. London: Routledge.

Hagan, John, \& Bill McCarthy (1998) Mean Streets: Youth Crime and Homelessness. Cambridge, England: Cambridge Univ. Press.

Harris, Judith Rich (1998) The Nurture Assumption: Why Children Turn Out the Way They Do. NY: Free Press.

Hebdige, Dick (1979) Subculture: The Meaning of Style. London: Methuen.

Henry, Stuart (2000) "What Is School Violence: An Integrated Definition," 567 The Annals of the American Academy of Political E' Social Science (Volume on School Violence) 16-29.

Henry, Stuart, \& Roger Eaton (1999) Degrees of Deviance: Student Accounts of Their Deviant Behavior, 2d ed. Sheffield, England: Sheffield Publishing Co.

Herdt, Gilbert \& Stephen C. Leavitt, eds. (1998) Adolescence in Pacific Island Societies. Pittsburgh, PA: University of Pittsburgh Press.

Hersch, Patricia (1999) A Tribe Apart: A Joumey into the Heart of American Adolescence. New York: Ballantine Books.

Hirsch, Susan F. (1998) Pronouncing and Persevering: Gender and the Discourse of Disputing in Kenyan Costal Courts. Chicago: Univ. of Chicago Press.

Horowitz, Ruth, \& Gary Schwartz (1974) "Honor, Normative Ambiguity and Gang Violence," 39 American Sociological Rev. 238-51.

James, A. (1986) "Learning to Belong: The Boundaries of Adolescence," in A. P. Cohen, ed., Symbolising Boundaries: Identity and Diversity in British Cul tures. Manchester, England: Manchester Univ. Press.

Jankowski, Martin Sanchez (1991) Islands in the Street. Berkeley, CA: Univ. of California Press.

Katz, Jack (1988) Seductions of Crime: A Chilling Exploration of the Criminal Mind from Juvenile Delinquency to Cold-Blooded Murder. New York: Basic Books. (1999) How Emotions Work. Chicago: Univ. of Chicago Press.

Koch, Klaus-Friedrich (1984) "Liability and Social Structure," in D. Black, ed., Toward a General Theory of Social Control, vol. 1, Fundamentals. New York: Academic Press.

Kohlberg, Lawrence (1981) The Philosophy of Moral Development: Moral Stages and the Idea of Justice. San Francisco: Harper \& Row.

Lamont, Michele (1992) Money, Morals, and Manners: The Culture of the French and the American Upper-Middle Class. Chicago: Univ. of Chicago Press.

Levinson, Bradley (1998) "The Moral Construction of Student Rights: Discourse and Judgement among Mexican Secondary School Students," $27 \mathrm{~J}$. of Contemporary Ethnography 45-84.

Levinson, Bradley, \& Dorothy Holland (1996) "The Cultural Production of the Educated Person: An Introduction," in B. Levinson, D. Foley, \& D. Holland, eds., The Cultural Production of the Educated Person: Critical Ethnographies of Schooling and Local Practice. Albany, NY: SUNY Press.

Lincoln, Yvonna S., \& Egon G. Guba (1985) Naturalistic Inquiry. Beverly Hills, CA: Sage.

Llewellyn, Karl, \& E. Adamson Hobel (1941) The Cheyenne Way: Conflict and Case Law in Primitive Jurisprudence. Norman, OK: Univ. of Oklahoma Press.

Long, Jennie J., William V. Fabricius, Michael Musheno, \& Dennis Palumbo (1998) "Exploring the Cognitive and Affective Capacities of Child Mediators in a 'Successful' Inner-City Peer Mediation Program,"15 Mediation Q. 289-300.

MacLeod, Jay (1987) Ain't No Makin' It: Aspirations and Attainment in a Low-Income Neighborhood. Boulder, CO: Westview Press. 
Males, Mike (1999) Framing Youth: Ten Myths about the Next Generation. Monroe, ME: Common Courage Press.

Massey, Doreen (1998) "The Spatial Construction of Youth Cultures," in T. Skelton \& G. Valentine, eds., Cool Places: Geographies of Youth Cultures. London: Routledge.

Matza, David, \& Gresham M. Sykes (1961) "Juvenile Delinquency and Subterranean Values," 26 American Sociological Rev. 37-49.

Maynard, Douglas (1985) "On the Functions of Social Conflict among Children," 50 American Sociological Rev. 207-23.

Maynard-Moody, Steven, \& Michael Musheno (2000) "State Agent or Citizen Agent: Two Narratives of Discretion." $10 \mathrm{~J}$. of Public Administration Research and Theory 329-58.

McRobbie, A. (1980) "Settling Accounts with Subcultures: A Feminist Critique." 34 Screen Education 37-49.

Merry, Sally Engle (1990) Getting Justice and Getting Even: Legal Consciousness among Working-Class Americans. Chicago: Univ. of Chicago Press.

Meyer, John W., John Boli, George M. Thomas \& Francisco M. Ramirez (1997) "World Society and the Nation State," 103 American J. of Sociology 144-81.

Miller, Walter B. (1958) "Lower Class as a Generating Milieu of Gang Delinquency," $14 \mathrm{~J}$. of Social Issues 111-21.

Miller, William Ian (1990) Bloodtaking. and Peacemaking: Feud, Law, and Society in Saga Iceland. Chicago: Univ. of Chicago Press.

Mills, C. Wright (1940) "Situated Action and Vocabularies of Motives," 5 American Sociological Rev. 904-13.

Moore, Sally Falk (1973) "Law and Social Change: The Semi-autonomous Social Field as an Appropriate Field of Study," 8 Law Ev Society Rev. 719-46.

Morrill, Calvin (1995) The Executive Way: Conflict Management in Corporations. Chicago: Univ. of Chicago Press.

Morrill, Calvin, Michelle Johnson, \& Tyler Harrison (1998) "Voice and Context in Simulated Everyday Legal Discourse: The Influence of Sex Differences and Social Ties," 32 Law E Society Rev. 639-66.

Nader, Laura (1990) Harmony Ideology: Justice and Control in a Zapotec Mountain Village. Stanford, CA: Stanford Univ. Press.

Nader, Laura, \& Harry F. Todd, eds. (1978) The Disputing Process: Law in Ten Societies. New York: Columbia Univ. Press.

Nagin, Daniel S., Greg Pogarsky, \& David P. Farrington (1997) "Adolescent Mothers and the Criminal Behavior of Their Children," 31 Law E Society Rev. 137-62.

Nussbaum, Martha S. (1995) Poetic Justice: The Literary Imagination and Public Life. Boston: Beacon Press.

Oberweis, Trish, \& Michael Musheno (1999) "Policing Identities: Cop Decisions and the Constitution of Citizens," 24 Law $\mathcal{E}^{\circ}$ Social Inquiry 897-923.

Pitt-Rivers, Julian (1965) "Honor and Social Status," in J. G. Peristiany, ed., Honour and Shame: The Values of a Mediterranean Society. Chicago: Univ. of Chicago Press.

Pollner, Melvin, \& Jill Stein (1996) "Narrative Mapping of Social Worlds: The Voice of Experience in Alcoholics Anonymous," 19 Symbolic Interaction 203-23.

Pressman, Jeffrey L., \& Aaron Wildavsky (1984) Implementation, 3d ed. Berkeley, CA: Univ. of California Press.

Proweller, Amira (1998) Constructing Female Identities: Meaning Making in an Upper Middle Class Youth Culture. Albany, NY: SUNY Press.

Riessman, Catherine Kohler (1993) Narrative Analysis. Newbury Park, CA: Sage.

Roberts, Simon (1979) Order and Dispute. London: Penguin Books.

Rodriguez, Luis J. (1993) Always Running. La Vida Loca: Gang Days in L.A. New York: Simon \& Schuster. 
Roe, Emery (1994) Narrative Policy Analysis: Theory and Practice. Durham, NC: Duke Univ. Press.

Sarat, Austin (1990) " . . . The Law Is All Over': Power, Resistance, and the Legal Consciousness of the Welfare Poor," 2 Yale J. of Law $\mathcal{E}$ the Humanities 343-79.

Schank, Roger C. (1990) Tell Me a Story: A New Look at Real and Artificial Memory. New York: Scribner's.

Schwartz, Gary (1972) "Youth Culture: An Anthropological Approach," in I. B. Casagrande, W. H. Goodenough \& E. A. Hammel, eds., Module 17 in the McCaleb Module in Anthropology Series. Lexington, MA: Addison-Wesley.

Scott, Marvin B., \& Stanford M. Lyman (1968) "Accounts," 33 American Sociological Rev. 46-62.

Shelden, Randal G., Sharon K. Tracy, \& William B. Brown (1997) Youth Gangs in American Society. Belmont, CA: Wadsworth.

Sibley, David (1995) Geographies of Exclusion. New York: Routledge.

Singer, Simon (1996) Recriminalizing Delinquency: Violent Juvenile Crime and Juvenile Justice Reform. Cambridge, England: Cambridge Univ. Press.

Skelton, Tracey, \& Gill Valentine, eds. (1998) Cool Places: Geographies of Youth Cultures. London: Routledge.

Snow, David A., \& Leon Anderson (1993) Down on Their Luck: A Study of Homeless Street People. Berkeley, CA: Univ. of California Press.

Spergel, Irving (1995) The Youth Gang Problem. New York: Oxford Univ. Press.

Strauss, Anselm L. (1987) Qualitative Analysis for Social Scientists. Cambridge, England: Cambridge Univ. Press.

Suchman, Mark C. (1997) "On Beyond Interest: Rational, Normative, and Cognitive Perspectives in the Social Scientific Study of Law," Wisconsin Law Rev. 475-501.

Suchman, Mark C., \& Lauren B. Edelman (1996) "Legal Rational Myths: The New Institutionalism and the Law and Society Tradition," 21 Law $\mathcal{E}^{\circ}$ Social Inquiry 903-42.

Sutton, John (1988) Stubborn Children: Controlling Delinquency in the United States, 1640-1981. Berkeley, CA: Univ. of California Press.

Thoits, Peggy (1990) "Emotional Deviance: Research Agendas," in T. D. Kemper, ed., Research Agendas in the Sociology of Emotions. Albany, NY: SUNY Press.

Thompson, John B. (1990) Ideology and Modern Culture: Critical Social Theory in the Era of Mass Communication. Stanford, CA: Stanford Univ. Press.

Thorne, Barrie (1994) Gender Play: Girls and Boys in School. New Brunswick, NJ: Rutgers Univ. Press.

Thrasher, Frederic (1927) The Gang: A Study of 1,313 Gangs in Chicago. Chicago: Univ. of Chicago Press.

Tucker, James (1999) The Therapeutic Corporation. New York: Oxford Univ. Press.

Valentine, Gill, Tracey Skelton \& Deborah Chambers (1998) "Cool Places: An Introduction to Youth and Youth Cultures," in T. Skelton and G. Valentine, eds., Cool Places: Geographies of Youth Cultures. London: Routledge.

Van Maanen, John (1988) Tales from the Field: On Writing Ethnography. Chicago: Univ. of Chicago Press.

Van Velsen, Jaap (1967) “The Extended Case Method and Situational Analysis," in A. L. Epstein, ed., The Craft of Social Anthropology. London: Tavistock.

Ward, Janie Victoria (1988) "Urban Adolescents' Conceptions of Violence," in C. Gilligan, J. V. Ward, \& J. M. Taylor, eds., Mapping the Moral Domain. Cambridge, MA: Harvard Univ. Press.

White, Hayden (1981) "The Value of Narrativity in the Representation of Reality," in W. J. T. Mitchell, ed., On Narrative. Chicago: Univ. of Chicago Press.

Willis, Paul (1977) Learning to Labour: How Working Class Kids Get Working Class Jobs. Westmead, England: Saxon House. 
Wilson, James Q., \& Richard Herrnstein (1985) Crime and Human Nature. New York: Simon \& Schuster.

Wright, Janet M. (in press) "Aside from One Little, Tiny Detail, We Are So Incredibly Normal: Perspectives of Children in Lesbian Stepfamilies," in M. Bernstein \& R. Reiman, eds., Queer Families, Queer Politics: Challenging Culture and the State. New York: Columbia Univ. Press.

Yngvesson, Barbara (1997) "Negotiating Motherhood: Identity and Difference in 'Open' Adoptions," 31 Law EO Society Rev. 31-80.

Zimring, Franklin (1998) American Youth Violence. New York: Oxford Univ. Press. 
